\title{
In Darker Shadows: Intelligence Analysis and Decision-Making behind the Overthrow of Guatemalan Democracy
}

William R. Weber

Follow this and additional works at: https://researchrepository.wvu.edu/etd

\section{Recommended Citation}

Weber, William R., "In Darker Shadows: Intelligence Analysis and Decision-Making behind the Overthrow of Guatemalan Democracy" (2017). Graduate Theses, Dissertations, and Problem Reports. 6928.

https://researchrepository.wvu.edu/etd/6928

This Thesis is protected by copyright and/or related rights. It has been brought to you by the The Research Repository @ WVU with permission from the rights-holder(s). You are free to use this Thesis in any way that is permitted by the copyright and related rights legislation that applies to your use. For other uses you must obtain permission from the rights-holder(s) directly, unless additional rights are indicated by a Creative Commons license in the record and/ or on the work itself. This Thesis has been accepted for inclusion in WVU Graduate Theses, Dissertations, and Problem Reports collection by an authorized administrator of The Research Repository @ WVU. For more information, please contact researchrepository@mail.wvu.edu. 
In Darker Shadows:

Intelligence Analysis and Decision-making Behind the Overthrow of Guatemalan Democracy

William R. Weber

\author{
Thesis submitted \\ to the Eberly College of Arts and Sciences \\ at West Virginia University \\ in partial fulfillment of the requirements for the degree of \\ Master of Arts in \\ History
}

James F. Siekmeier, Ph.D., Chair

Michelle M. Stephens, Ph.D.

David M. Hauser, Ph.D.

Department of History

Morgantown, West Virginia

2017

Keywords: CIA; Guatemala; Analyst; Intelligence Community; Cold War; Eisenhower; Árbenz; Covert Action, Decision-making Copyright 2017 William R. Weber 


\begin{abstract}
In Darker Shadows:

Intelligence Analysis and Decision-making Behind the Overthrow of Guatemalan

Democracy
\end{abstract}

William R. Weber

In 1954 the CIA aided in the overthrow of Guatemala's democratically elected president. Jacobo Árbenz Guzman, a leftist leader intent on improving the quality of life for Guatemala's lower class population, nationalized tens of thousands of acres of private land for redistribution to the peasantry as part of an agrarian reform law, which was also supported by Guatemala's small communist party. The United Fruit Company (UFCo), a US company which dominated Guatemala's agricultural export market, had thousands of unused acres expropriated. UFCo, with ties to high-level government officials, appealed to the US State Department for resolution to this injustice. President Eisenhower and many in his Cabinet felt the land reform legislation and Árbenz' nationalist policies were likely backed by Moscow and decided to use covert action to ensure communism was rolled back from the hemisphere.

President Eisenhower saw covert action as a low-cost, low-visibility method to achieve U.S. policy objectives abroad. Having seen covert action produce legitimate results in World War II with the Office of Strategic Services, during the Italian elections in 1948, and in Iran in 1953, the president came to trust in the effectiveness of covert action and its practitioners. The CIA, in addition to providing the covert action experts who carried out the president's foreign policy objectives, also provided the president with expert analysis about the ever changing situation in Guatemala. From 1950 until Árbenz' overthrow in 1954, CIA analysts provided the president and his advisors with a number of reports which supported some of the judgements that Eisenhower's advisors were already making. My study seeks to demonstrate the nature of CIA analytic assessments and will show Eisenhower's affinity for intelligence and covert action. This thesis will also review the types of information available to Eisenhower and his decision-making strategy. Ultimately, I argue that the 1954 Guatemalan coup cannot be fully understood without looking at what CIA analysts were telling high-level policymakers, how that intelligence integrated with other sources available to those policymakers, and how this combination of information emboldening Eisenhower to authorize covert action to overthrow Árbenz. 


\section{ACKNOWLEDGEMENTS}

Intelligence analysts often start an assessment with their BLUF-their Bottom Line Up Front. Their analytic products are often drafted for policymakers possessing limited time for consumption and who therefore prefer the main points and judgements plainly presented at the beginning. That being said, from the outset and very pronouncedly, I would like to thank my mom. Pursuing my master's degree required encouragement from my family and friends and my strongest advocate was her, even to her last breath, which she peacefully took while I was working on this study. I love and miss you mom.

To my dad, brother, sister, in-laws, and dear friends... thank you for often adjusting your lives to meet the hectic schedule I subjected myself to. I am in your debt.

To my advisor, Dr. James Siekmeier, thank you for the countless hours spent developing me as a scholar and for the enthusiasm you showed for my research topic. Your suggestions and guidance has helped me analyze information from different perspectives and more than once has helped me overcome what I thought might be a dead end. To David Abruzzino, thank you for the introduction to intelligence history, your friendship, and the encouragement you have constantly given. Dr. Michele Stephens and Dr. David Hauser, thank you for the encouragement and advice and for the thought provoking coursework you offered.

The research librarians at the Eisenhower Presidential Library, Museum, and Boyhood Home proved invaluable in helping me find documents from Eisenhower's time as president, and refine my search in such a way as to maximize my short visit to Abilene. Mary Burtzloff and Nicole Beck, thank you and I hope to visit Ike's home again soon.

This study investigates the influence of intelligence analysts on the foreign policy of President Eisenhower. Thank you to all who have sat with patience as I excitedly shared what I have learned. 


\section{CONTENTS}

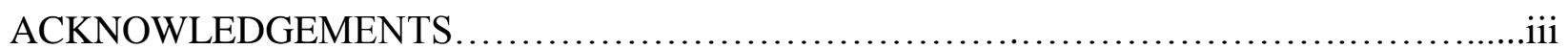

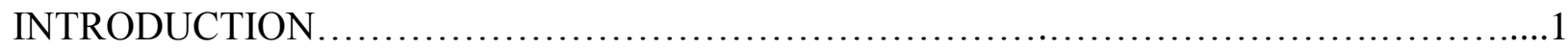

ORIGIN OF RESEARCH QUESTION ..........................................

THE GUATEMALAN REVOLUTION..........................................4

EXISTING SCHOLARSHIP ....................................................

STUDY STRUCTURE.................................................... 14

CHAPTER 1: EARLY COLD WAR NATIONAL SECURITY ..............................16

THE ORIGINS OF THE INTELLIGENCE COMMUNITY ........................ 16

US COLD WAR POLICY: NSC 68 VS THE NEW LOOK.........................25

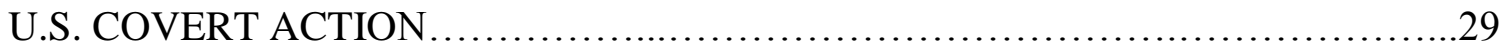

CHAPTER 2: PBSUCESS, ANALYSIS, AND THE NSC ..................................

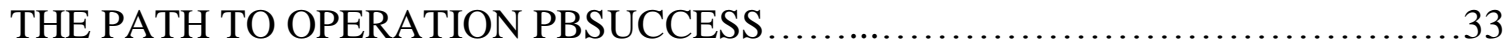

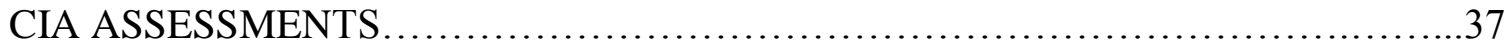

OFFICE OF NATIONAL ESTIMATES ....................................41

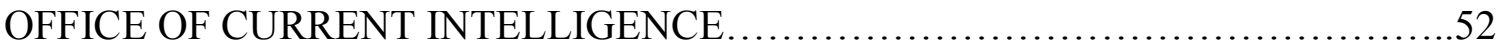

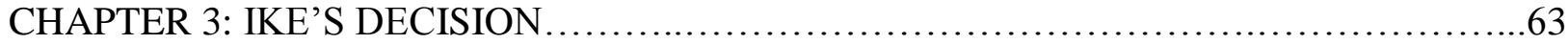

EISENHOWER'S SOURCE................................................63

US FOREIGN POLICY AND THE DULLES BROTHERS....................64

US MEDIA AND PUBLIC OPINION ...................................69

UNITED FRUIT COMPANY ........................................72

EISENHOWER'S LEARNING STYLE, PSYCHOLOGY, AND DECISION

MAKING........................................................... 74

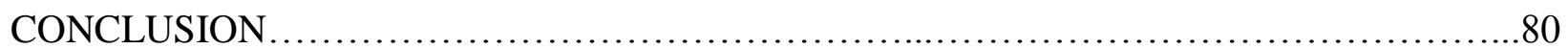

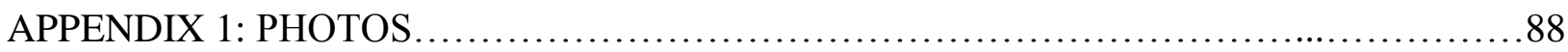

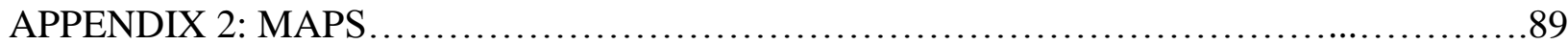

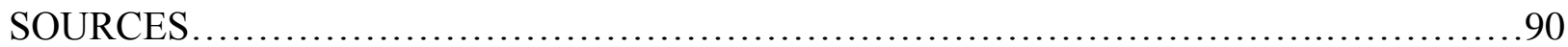




\section{INTRODUCTION}

On the afternoon of 27 June 1954, smoke plumed in the midday heat of a modest Central American capital, and explosions sounded nearby as Jacobo Árbenz Guzman approached a microphone set up at a makeshift radio broadcast studio. Overcome with grief at the state of affairs in his besieged country, he addressed his countrymen, saying:

"Workers, peasants, patriots, my friends, people of Guatemala: Guatemala is enduring a most difficult trial. For fifteen days a cruel war against Guatemala has been underway. The United Fruit Company, in collaboration with the governing circles of the United States, is responsible for what is happening to us....

I have not violated my faith in democratic liberties, in the independence of Guatemala and in all the good that is the future of humanity.... I have always said to you that we would fight regardless of the cost, but the cost should not include the destruction of our country and the sending of our riches abroad. And this could happen if we do not eliminate the pretext that our powerful enemy has raised.

A government different from mine, but always inspired by our October Revolution, is preferable to twenty years of fascist bloody tyranny under the rule of the bands that Castillo Armas has brought into the country."1

In 1954, the United States government, via the Central Intelligence Agency, at the urging of President Dwight Eisenhower, supported the overthrow of Jacobo Árbenz from the presidency of Guatemala. The CIA and State Department used extensive propaganda, radio broadcasts, economic sanctions, manipulation of humanitarian aid, and paramilitary activity to achieve this. The US was at odds with its own institutional values when it overthrew the legitimate administration of a democratically elected foreign president. The coup d'état that ousted Árbenz has been thoroughly research over the years, and many dramatically nuanced accounts of the event exist. The major scholarly differences lay in how historians interpret the motivating factors which led the U.S. government to intervene in a sovereign nation.

\footnotetext{
${ }^{1}$ Árbenz addresses Guatemala, 27 June 1954, from Stephen Kinzer, Overthrow: America's Century of Regime Change from Hawaii to Iraq (New York: Times Books, 2006), 145.
} 
This study examines the role of intelligence analysts and their reporting during President Eisenhower's first term in the White House. More specifically, this study seeks to determine how the president used intelligence to inform his decisions, particularly in regards to the authorization of covert action undertaken by the Central Intelligence Agency (CIA) to overthrow Guatemala's president. First, it examines the nature and development of assessments by CIA and other Intelligence Community (IC) entities regarding Guatemala under Jacobo Árbenz. Then it explores the bureaucratic intricacies that composed Eisenhower's administration, introducing layers of discussion and review into the policy making process. These things are essential, this thesis argues, to understanding the nuanced manner behind President Eisenhower's decision making process and his authorization of the Árbenz overthrow operation. The U.S. intervention in Guatemala provides an ideal case study for exploring the pathways used by senior policymakers under Eisenhower to develop foreign policy decisions which utilized covert action for policy implementation. Guatemala was, in 1954, experiencing its tenth year of revolutionary democracy and exhibited strong nationalist tendencies which were often interpreted by the U.S. as being influenced by communism. Because of this, by the end of the summer in 1953, the Eisenhower administration felt obligated to act in order to roll back a perceived threat. This study argues that understanding the overthrow requires a deeper understanding of the CIA analysts who worked to inform policymakers about the situation in Guatemala, what those analysts assessed, how their reports integrated with other information sources, and how Eisenhower made decisions. The interpretation of these items will offer a clearer picture as to why Eisenhower opted to remove a democratically elected foreign leader. 


\section{ORIGIN OF RESEARCH QUESTION}

Diplomatic historian Stephen Streeter, known for his research of Guatemala after the 1954 overthrow, posits that despite a rich historiographic record of the overthrow, room for additional scholarship exists within the context of the "Eisenhower administration's decision to topple Árbenz." 2 This is where I decided to begin. While investigating the overthrow of Guatemalan President in Nick Cullather's Secret History: The CIA's Classified Account of Its Operations in Guatemala, 1952-1954 I discovered that CIA analysts, then part of the Directorate of Intelligence (DI), were excluded from PBSUCCESS, the moniker given to the covert operation, by Frank Wisner-the senior Directorate of Plans officer put in charge of the operation by DCI Allen Dulles. ${ }^{3}$ Cullather utilizes numerous correspondences and reports between Directorate of Plans officers - those who had, or directed, "boots on the ground"-but relied marginally on DI products to shape his narrative. Since analysts inform policymakers, I found the exclusion of the DI from the operation to be of interest. I wanted to know what information President Eisenhower utilized in formulating his decision to authorize PBSUCCESS. The CIA and other analysts throughout the IC did author numerous reports during the late 1940s and early 1950s regarding Soviet intentions and capabilities in Latin America, but did the intelligence failures of the Korean conflict create an "atmosphere of declining confidence" in intelligence analysis? ${ }^{4}$ My research seeks to determine the role that CIA intelligence analysts played in the overthrow and examine the assessments and estimates produced during this time in

\footnotetext{
${ }^{2}$ Stephen Streeter, "Interpreting the 1954 US Intervention in Guatemala: Realist, Revisionist, and Postrevisionist Perspectives," The History Teacher 34 (November 2000): 13.

${ }^{3}$ Nick Cullather, Secret History: The CIA's Classified Account of Its Operations in Guatemala, 1952-1954 Stanford: Stanford University Press, 1999), 44.

${ }^{4}$ Roger Z. George reviews John Diamond, The CIA and the Culture of Failure: US Intelligence from the End of the Cold War (Stanford: Stanford University Press, 2008), 536 p., for Intelligence in Public Literature, (21 April 2009), https://www.cia.gov/library/center-for-the-study-of-intelligence/csi-publications/csistudies/studies/vol53no1/the-cia-and-the-culture-of-failure-u.s..html (accessed 20 July 2017).
} 
order to determine whether or not President Eisenhower did, in fact, trust and utilize analytic work, or if he had a predisposition for information coming straight from his "boots on the ground" officers, advisors, other sources, and/or his personal bias.

Additionally, if President Eisenhower did neglect analysts' judgements in favor of alternative information sources, my research seeks to explore the implications this had on the operation as well as later U.S. policy in Latin America. Numerous scholars suggest the relative success of the 1954 overthrow in Guatemala emboldened later covert action efforts in Cuba. My research seeks to determine if senior CIA officers and national level policymakers marginalized CIA analysts and whether or not that trend continued, thus impacting later events, or if analytic products were in fact used, perhaps even to further organizational agendas. Ultimately, I believe the 1954 overthrow of Árbenz can only be fully understood when an interpretation of the analyst's contributions and an evaluation of President Eisenhower's decision making process is explored.

\section{THE GUATEMALAN REVOLUTION}

Scholars largely accept that the Guatemalan revolutionary movement that overthrew proU.S. caudillo Jorge Ubico in 1944 was the result of liberal democratic ideals championed by leaders like Franklin D. Roosevelt of the U.S. and Lazaro Cardenas of Mexico. ${ }^{5}$ After a popular uprising led by school teachers and middle class citizens, Juan Jose Arévalo became Guatemala's first elected president and installed a democratic government. Arévalo also implemented numerous reforms, including an increase in the minimum wage, removal of harsh vagrancy laws, and distribution of land to peasants which had been confiscated during World War II from

\footnotetext{
${ }^{5}$ Stephen Rabe, Eisenhower and Latin America: The Foreign Policy of Anticommunism (Chapel Hill: University of North Carolina Press, 1988), 43.
} 
Germans. ${ }^{6}$ Researchers Stephen Schlesinger and Stephen Kinzer categorized Arévalo's administration as a new form of socialism, albeit a democratic and egalitarian form. The FBI, under J. Edgar Hoover, still maintained jurisdiction of Central and South America, opened a dossier on Arévalo, and maintained its scrutiny of Guatemala well into the Árbenz administration. ${ }^{7}$ In March 1951, another first for Guatemala occurred, as the peaceful transition of one elected official to another occurred with Jacobo Árbenz Guzman's ascension to the presidential office. Árbenz continued Arévalo's nationalist policies, but with more fervor, and in 1952 championed the Agrarian Reform Law, or Decree 900. The Agrarian Reform Law's goal was to expropriate, after compensation, unused agricultural land for redistribution to the peasantry. Árbenz believed peasants could farm for subsistence and also contribute any excess to free-markets, raising the gross domestic product, which would in turn aid in modernization. The uncultivated land would come from latifundias, or plantations, many of which were owned by large corporations like United Fruit Company (UFCo) of Boston. At two of its largest plantations UFCo lost roughly 407,000 of 548,000 acres, and was compensated only five percent of what UFCo assessors valued the land. Enraged, the company, with extremely close ties to very prestigious members of Eisenhower's staff, lobbied Washington for assistance. ${ }^{8}$ Many within the U.S. government believed Árbenz’ land reform agenda moved Guatemala irreversibly towards radicalization and communization of the country.

\footnotetext{
${ }^{6}$ Stephen Rabe, Eisenhower and Latin America , 44. Rabe mentions this, but does not expand. Max Paul Friedman's Nazis \& Good Neighbors: The United States Campaign against the Germans of Latin America in World War II (Cambridge: Cambridge University Press, 2003), outlines the extensive program run by the FBI in Latin America during the Second World War to uproot potential Nazi spies and saboteurs. His argument is that an extensive German population was uprooted from Latin America and interned in camps in the southern US, often with no incriminating evidence, and at times because social or political rivals in Latin America desired German property.

${ }^{7}$ Stephen Schlesinger and Stephen Kinzer, Bitter Fruit: The Untold Story of the American Coup in Guatemala (Garden City, NY: 1982), 39-40.

${ }^{8}$ Piero Gleijeses, Shattered Hope, The Guatemalan Revolution and the United States, 1944-1954 (Princeton: Princeton University Press, 1991), 164.
} 


\section{EXISTING SCHOLARSHIP}

The 1954 overthrow of President Árbenz, a textbook example of covert action employed to further U.S. Cold War policy objectives, has been widely chronicled by scholars since the 1950s. Several schools of thought emerge as the dominant frameworks used by scholars to structure their narratives. These include Cold War realism, economic nationalism, international aid, covert action implementation, dependency theory, and indigenous agency. ${ }^{9}$ Stephen Streeter authored a short article for The History Teacher in late 2000 which outlined the nuanced approaches used to understand the U.S. intervention in Guatemala, exploring this via three primary historical frameworks: realism, revisionism, and post-revisionism. ${ }^{10}$ Many of the most noteworthy books authored on this topic are expertly discussed in Streeter's article, namely Bitter Fruit by Stephen Schlesinger and Stephen Kinzer, The CIA in Guatemala: The Foreign Policy of Intervention by Richard Immerman, Shattered Hope: The Guatemalan Revolution and the United States, 1944-1954 by Piero Gleijeses, and Secret History by Nick Cullather. Streeter also mentions scholarly articles written by Jim Handy, but does not mention Handy's book, Revolution in the Countryside: Rural Conflict and Agrarian Reform in Guatemala, 1944-1954. Handy's book strays from the central focus of the aforementioned books in that he focuses on the agency of Guatemala's rural indigenous participants during the revolution of 1944-1954.

In the atmosphere of the Cold War struggle for power, many realist narratives emerged in the 1950s and 1960s which positioned President Árbenz as a communist and puppet of Moscow, which justified U.S. intervention as a means to counter Soviet power projection. Streeter

\footnotetext{
${ }^{9}$ James Siekmeier, Aid, Nationalism, and Inter-American Relations: Guatemala, Bolivia, and the United States, 1945-1961 (New York:1999), is an excellent source of the expansive history of US support and later suppressive policy towards economic nationalism, especially during war time (WWII and the Cold War). The revolutions in Guatemala and Bolivia are outlined in later chapters, as well as changes in policy during Eisenhower's second term, especially in terms of aid provided to these two nations as dependency on the US is maintained and expanded.

${ }^{10}$ Streeter, "Interpreting the 1954 US Intervention in Guatemala," 13.
} 
suggests that "certain interpretations can be laid to rest" now the scholarly examination of previously closed archives has been completed. ${ }^{11}$ Namely, counter to realist interpretation, Moscow was not in control of Árbenz in 1954, nor were the Soviets interested in Guatemala during the early fifties.

The emergence of the New Left in the 1960s also sparked the revisionist movement which sought to blame the United States for many of the troubles in the third world, claiming U.S. policy was a form of economic imperialism. ${ }^{12}$ Revisionists dubbed Árbenz a nationalist, not a communist, and claimed that the U.S. acted to ensure hegemonic control of markets in the hemisphere. The most notable revisionist account of the overthrow was Bitter Fruit by Schlesinger and Kinzer, who argue that United Fruit Company, which was drastically affected by land reform action taken by Árbenz, and had significant ties to high-level U.S. government officials, played a key role in the intervention. Schlesinger and Kinzer tendered several Freedom of Information Act (FOIA) requests to the CIA and other agencies but did not receive them prior to publishing in 1982, but used a variety of alternative sources, which Streeter calls "selective and circumstantial." 13 Kinzer and Schlesinger focus extensively on U.S. Ambassador John Peurifoy, who they state "[arrived] in the country, attempting without success to settle the issue of compensation for the property seized from the United Fruit Company under Guatemala's land reform act." They also illuminate the fact that the "United States ambassador, in an unusual role, had actually acted as the company's representative in the negotiations with Guatemala." 14

In the 1980s and 1990s, post-revisionist narratives emerged, aligning with revisionists in the acceptance of Moscow's role in the affair, while straying from revisionists by suggesting it

\footnotetext{
${ }^{11}$ Stephen Streeter, "Interpreting the 1954 US Intervention in Guatemala," 12.

${ }^{12}$ Stephen Streeter, "Interpreting the 1954 US Intervention in Guatemala," 4-5.

${ }^{13}$ Stephen Streeter, "Interpreting the 1954 US Intervention in Guatemala," 6.

${ }^{14}$ Stephen Schlesinger and Stephen Kinzer, Bitter Fruit, 15.
} 
was not United Fruit Company or economic imperialism that prompted the intervention, but rather a combination of "political, strategic, economic, psychological, and ideological factors." 15 Immerman's book, The CIA in Guatemala, suggests that Eisenhower confused nationalism with communism and that the CIA was absolutely necessary for the overthrow of Árbenz by Colonel Carlos Castillo Armas, the right-wing military leader backed by PBSUCCESS operations. Unlike Kinzer and Schlesinger, Immerman was able to acquire many previously classified documents through FOIA requests and presented a detailed account of the clandestine operation in Guatemala. Piero Gleijeses's Shattered Hope continues on the post-revisionist tract, suggesting there is no single "convenient villain," but does something other post-revisionist fail to do: include the Guatemalan voice. ${ }^{16}$ Gleijeses focuses largely on Guatemala's urban economic and political narrative. He also suggests that United Fruit Company had lost some pull in government circles and that officers at the CIA and State Department were far more influential at driving policy than lobbyists from UFCo. Gleijeses also offers additional detail regarding the total acreage lost by UFCo under the Árbenz land reform strategy. ${ }^{17}$

A short yet useful post-revisionist monograph, Nick Cullather's book, Secret History, was originally an in-house narrative written for CIA employees to enhance their understanding of the operation. ${ }^{18}$ Written in 1992 and released to the public in the late nineties, Secret History emphasized the national security imperatives that prompted Eisenhower to act. At the outset of Cullather's interpretation of CIA records, he states that:

\footnotetext{
${ }^{15}$ Stephen Streeter, "Interpreting the 1954 US Intervention in Guatemala," 7.

${ }^{16}$ Gleijeses, Shattered Hope, 361.

${ }^{17}$ Piero Gleijeses, Shattered Hope, 164.

${ }^{18}$ Nick Cullather was a CIA historian with access to then classified documents in 1992 when he first wrote his seminal book, Secret History: The CIA 's Classified Account of Its Operations in Guatemala, 1952-1954. His account is largely a timeline of the operations, for the first time drawing on official CIA documents to support his research. It was later declassified for public consumption, albeit with significant redaction.
} 
Some accuse the Eisenhower administration and the Agency of acting at the behest of self-interested American investors, particularly the United Fruit Company. Others argue that anti-Communist paranoia and not economic interests dictated policy, but with equally regrettable results. ${ }^{19}$

Cullather immediately follows this by explaining that the CIA records he studied do not directly resolve questions posed by these statements, but offer explanations on the "conduct of operations, how Agency operatives construed the problem, what methods and objectives they pursued, and what aspects of the operations they believed led to success. ${ }^{, 20}$ Stephen Streeter, in his review of Cullather's work in his article Interpreting the 1954 US Intervention in Guatemala, suggests that the CIA "got lucky" during the overthrow because a factor the CIA had not considered — the morale level of the Guatemalan army—ultimately resulted in Armas' victory. ${ }^{21}$ Senior leadership in the Eisenhower administration approved the operation with a very weak exit strategy, yet also believed that success could be attributed to the culmination of their impressive planning. In reality, CIA misunderstood the disposition and attitude of the Árbenz military, and victory was ultimately a result of factors not anticipated. This led CIA leadership to prepare illinformed after-action reports for the administration, and Cullather notes that this may have set a precedent for future operations, such as the Bay of Pigs. ${ }^{22}$

Cullather spends some time explaining the Partido Guatemalteco del Trabajo (Guatemalan Party of Labor-PGT), which began as a mostly conservative union coalition party called the Partido Acción Revolucionaria (Revolutionary Action Party—PAR). PAR fractured after the 1950 election with members like Víctor Manuel Gutiérrez and José Manuel Fortuny separating themselves from the organization and establishing a union centered on Marxist

\footnotetext{
${ }^{19}$ Nick Cullather, Secret History, 8.

${ }^{20}$ Nick Cullather, Secret History, 8.

${ }^{21}$ Stephen Streeter, "Interpreting the 1954 US Intervention in Guatemala," 11.

${ }^{22}$ Cullather, Secret History, 109-110. Barrett, Sterilizing a "Red Infection" Congress, the CIA, and Guatemala, 1954, briefly discussed later, also notes that perceived success in Guatemala falsely informed policymakers and covert action planners when they formulated the Bay of Pigs plan.
} 
ideology, organizing in favor of the proletariat. ${ }^{23}$ Cullather notes that "PGT contributed little to Árbenz' victory in 1950," but that once Árbenz was in office, he relied ever increasingly on their advice, most notably Fortuny's and Gutiérrez's hand in drafting the controversial land reform policies found in Decree 900. However, Cullather notes, as Schlesinger and Kinzer and other scholars do, that only four seats out of sixty-one congressional seats were held by PGT members, and no cabinet seats were occupied by communists, indicating communist influence was not as abundant as it was suggested. ${ }^{24}$

The overall character and premise of Cullather's book is displayed in the final sentences of the first chapter: "Truman and Eisenhower saw Guatemala as succumbing to communist pressures emanating ultimately from Moscow. The threat to American business was a minor part of the larger danger to the United States' overall security. ${ }^{25}$ Cullather's monograph suggests that while economic problems, personified in the United Fruit case, were present, the threat of communism was the larger factor which led the US to intervene in Guatemala. ${ }^{26}$

Most scholars, especially with the declassification of documents at the Dwight D. Eisenhower Presidential Library, FOIA requests from the CIA, and other recently declassified documents, agree that the role Eisenhower and the CIA had in overthrowing Árbenz was greater than Eisenhower alluded to in his memoirs. ${ }^{27}$ Post-revisionist scholars now take the middle ground, suggesting that Eisenhower's policy was a combination of disinterest and interventionist, such that he wanted to avoid massive troop commitments and nuclear war, but was accepting of covert action methods of subverting communist activity. ${ }^{28}$ This aligns with Cullather's reference

\footnotetext{
${ }^{23}$ Cullather, Secret History, 14-24.

${ }^{24}$ Cullather, Secret History, 21.

${ }^{25}$ Cullather, Secret History, 37.

${ }^{26}$ Cullather, Secret History, 36-37.

${ }^{27}$ Stephen Rabe, Eisenhower and Latin America, 4-5.

${ }^{28}$ Rabe, Eisenhower and Latin America, 5.
} 
to the "New Look" policy, discussed in more detail in chapter one of this study. ${ }^{29}$ Historian Stephen Rabe notes that Eisenhower felt "Guatemalan leaders violated both the national security decisions and the foreign economic policies of the United States," and suggests that emphasizing either motive over the other is unneeded, also citing intelligence documents which state simply "the current political situation in Guatemala is adverse to US interest." 30

Historian Greg Grandin contributed an essay entitled What Was Containment? Short and Long Answers from the Americas to Robert McMahon's book titled The Cold War in the Third World, suggesting that for Latin America, the Cold War should not be viewed within the standard Cold War realism, economic nationalist, or dependency models, but as a piece of a much larger revolutionary narrative situated in the entirety of the twentieth century. ${ }^{31}$ Grandin argues that insurgencies and radicalizations in the 1950s were the result of influential global ideologies which manifest themselves in Latin America, and events like the Cuban Revolution transformed "Old Left" revolutionary efforts, which he classifies as internal, into globally noteworthy and "externalized" efforts. These externalized efforts resulted in a culture of radicalization in the 1960 s onward. ${ }^{32}$ Additionally, Grandin argues that containment had a different meaning to those in Latin America, who were used to decades of interference from the U.S. To Latin America, containment was "counterrevolutionary" and in "response to third-world nationalism." ${ }^{33}$ As some of the other scholars previously discussed have done, Grandin also cites Kennan's "racist" 1950 report on Latin America noting that Latin American "socialization of U.S. liberalism" worked in principle during the Second World War, but paternalistic perception

\footnotetext{
${ }^{29}$ Cullather, Secret History, 35-37.

${ }^{30}$ Rabe, Eisenhower and Latin America, 58-59.

${ }^{31}$ Robert J. McMahon, The Cold War in the Third World (Oxford: Oxford University Press, 2013), 27.

${ }^{32}$ McMahon, The Cold War in the Third World, 28.

${ }^{33}$ McMahon, The Cold War in the Third World, 29.
} 
of Latin America made it inconsistent with U.S. Cold War policy. ${ }^{34}$ In conclusion, his essay positions containment, traditionally viewed from the U.S. perspective, within a Latin American framework, thus offering a nuanced and fresh analysis to the standard interpretation.

Post-revisionism has been classified as vague and ambiguous, which lends itself to subtly different interpretations, but makes it difficult to pinpoint a precise cause for events like the Guatemala intervention. This study is distinctive, because it seeks to understand the role of CIA analysts and their assessments in the decision making process of the president. Post-revisionists explore the intricate combination of influences that prompted Eisenhower to interfere in Guatemala, just as this study will by using bureaucratic politics as a framework for interpretation. Further, what this work seeks to do is synthesize and fuse historical interpretation with social science by attempting to understand how politics and psychology set the conditions for the coup and by using this as a basis for understanding Eisenhower's decision making process. Further, this study will show that Eisenhower was predisposed to use covert action, as most scholars agree, and that those advisors and Cabinet members closest to him were as well. This created an environment akin to groupthink, despite best efforts to make thoughtful decisions regarding foreign policy. This study will focus on that decision making effort, integrating intelligence analysis into the narrative since the sole responsibility of analysts is to reduce uncertainty for policy makers engaged in formulating policy. What follows is a complex narrative of that process.

This is certainly not the first interpretation of the events in Guatemala. However, my research should be considered important because it offers a different interpretation of U.S. policy in the early Cold War regarding Latin America and explores an aspect of the U.S. intelligence apparatus that seldom receives attention. Furthermore, it seeks to highlight the decision making

\footnotetext{
${ }^{34}$ McMahon, The Cold War in the Third World, 41-42.
} 
process utilized by President Eisenhower and how intelligence analysis and other means factored into that. Using the 1954 coup in Guatemala as a case study, my research seeks to focus on the various information sources that influenced the president, resulting in his decision to use covert action in Guatemala. It will contribute to knowledge by highlighting the often marginalized analysts whose assessments and estimates helped shape policy, the early misunderstanding of intelligence functions by policymakers, as well as establish (and further corroborate) the basis for covert action affinity by early Cold War practitioners. I believe by understanding the work of intelligence analysts during the 1950s, we can further our understanding of their role today, thus adding additional relevance to my research. Because so much of the scholarship surrounding the CIA overthrow of President Árbenz has focused on the economic, operational, and political factors, I will contribute to the cumulative narrative by showing how intelligence analysts participated and demonstrate their level of relevance to Eisenhower's decision making. Numerous scholars have shown the connectedness of United Fruit, Eisenhower, and his staff. Still, others have worked to give an extensive account of the covert operation itself. My research seeks to look at this action through the work of a different participant, and marry that to policymaking. I use primary source material to elucidate the policymaker's disposition regarding global affairs in the early 1950s, and use that understanding to discuss the intelligence products drafted by CIA analysts. I believe that synthesizing our understanding of intelligence analysis history, the national attitude, Eisenhower's decision making process, and policy objectives will offer a nuanced interpretation of the overthrow operation, and demonstrate how early analysts worked diligently to inform policymakers, despite final decisions resting outside of analyst's control. I believe this has relevance in today's strategic environment, as intelligence analysts continue to draft reports to reduce uncertainty for the President. Finally, my research is unique 
because it offers details about the relevancy of a sidelined group of professionals who are important to the policymaking process, and does so by assessing their role and influence in Eisenhower's covert action policy. This study seeks to highlight the interconnectedness of intelligence tradecraft, history, and the psychology and methodology behind executive decision making, and in doing so offer a new look at the 1954 Guatemalan coup.

\section{STRUCTURE OF THIS STUDY}

This study is formatted in such a way as to provide adequate background information about the various topics at play throughout the narrative-U.S. foreign policy towards Latin America, the advent and evolution of intelligence analysis and the intelligence profession, the Guatemalan Revolution, covert action, Cold War policy, and Eisenhower and his staff. Volumes exist for each of these topics, so it is necessary within my introduction to outline much of this information in a succinct yet logical manner. I explain the origins of my research question and what supplemental questions have guided my research. To understand the sociopolitical environment in Guatemala during the early and mid-1950s, I included a section on the Guatemalan Revolution. Then transitioning to chapter one, I give a progressive review of the origins of the U.S. intelligence community that existed during the 1950s and explain the many facets involved with intelligence in the U.S. Explaining the intelligence cycle and the various intelligence collection disciplines will give the reader adequate comprehension of the issues discussed within this paper. Early Cold War policy under President Truman had slightly different aims than the policy introduced by Eisenhower's staff, so chapter one concludes by exploring the differences between these two polices as well as a discussion on covert action as an extension of policy. 
Chapters two and three dive into the substance of my historical interpretation. It is in chapter two that I explain the operation conducted by the U.S. government to overthrow President Árbenz. I introduce, analyze, and discuss the significance of the key primary sources used for this study. The various CIA analytic products produced during the time period give important insight into what policymakers knew and how decisions were formed. Once these documents are assessed, I review additional sources of influence to President Eisenhower and his staff. Business issues, diplomatic efforts, U.S. public opinion, the media, and closed door staff meetings are discussed at the end of chapter two. This aids with the transition to chapter three, driving directly into the factors behind Eisenhower's decision to launch PBSUCCESS. The chapter discusses those closest to Ike and who may have influenced him. It also dissects Eisenhower's management and learning styles, and how he and his advisors interacted and came to important decisions. Scholars have interpreted Eisenhower's decision making process and involvement in policymaking in drastically different ways, and chapter three intends to offer nuance as well as solidify the revisionist idea of Eisenhower as a political leader.

I conclude this study by summarizing Eisenhower's decision to launch a covert action operation against Guatemala after having reviewed the information available to him as well as how he interacted with his staff when forming policy. Further, the summary will discuss Eisenhower's leadership style, as well as the significant influence key advisors had throughout his administration. Lastly, the conclusion will briefly discuss the theory of intelligence failure and discuss whether or not the 1954 coup was an intelligence failure, a policy failure, or something else. The oppression and corruption that plagued Guatemala is addressed, highlighting the historical significance of my research by emphasizing the lessons learned from PBSUCCESS and President Eisenhower decision. 


\section{CHAPTER 1: EARLY COLD WAR NATIONAL SECURITY}

\section{THE ORIGINS OF THE INTELLIGENCE COMMUNITY}

The history of intelligence in the United State dates to the nation's founding. Intelligence played a significant part of the Revolutionary War, from Paul Revere's midnight ride warning the Sons of Liberty at Lexington and Concord, to the information John Honeyman provided George Washington about Hessian movement and disposition at Trenton. Furthermore, the notable Culper ring in New York City, a covert group of merchants, farmers, and longshoreman, relayed to Washington, via his intelligence chief Major Benjamin Tallmadge, a message regarding British troop movement from the city to the Rhode Island coast. The British intent was to intercept and turn back arriving French troops. If the British succeeded in repelling the French landing force, American forces would likely face disaster in the coming months. Armed with the information from his New York spies, Washington deployed a diversionary action, surrounding areas of the city, thus evoking the British commander to recall his troops, allowing the French to land unopposed. The arrival of these French troops sealed the fate of the British in the American colonies. ${ }^{35}$

Today, the U.S. Intelligence Community (IC) operates in a predominantly cyclical fashion. The ultimate objective of intelligence is to provide timely, accurate, concise information to policymakers in order to facilitate the reduction of uncertainty in the decision making process. This information does not eliminate uncertainty, but it affords the policymaker with the best information available to ensure the best decisions are made. Policymakers provide the IC with information requirements, which are then prioritized and passed on to various collection entities. Collection takes place using of variety of different methods, “-ints", such as human intelligence,

\footnotetext{
${ }^{35}$ G.J.A. O'Toole, Honorable Treachery: A History of Intelligence, Espionage, and Covert Action from the American Revolution to the CIA (New York: Atlantic Monthly Press, 1991), 9-79.
} 
or HUMINT; communications intelligence, COMINT; signals intelligence, SIGINT; or open source intelligence, or OSINT; just to name a few. Once the information collection has been completed, it is processed and provided to analysts for interpretation. The intelligence analyst, a subject matter expert, adds value to the collected information by better explaining what the information shows, and coalescing the information with other sources of information from other collection platforms. Ultimately, the analyst will produce an intelligence assessment, which is then disseminated back to the policymaker. This cyclical system was not fully implemented until the 1940s, with the advent of a deliberately formed centralized intelligence organization.

The surprise attack on Pearl Harbor in 1941 prompted Washington to enter World War II. Additionally, it laid bare a bureaucratic deficiency regarding the collection, synthesis, production, and dissemination of intelligence. It was during the ensuing War that the growth of intelligence as a lasting professional occupation occurred within the United States, and the consolidation of information for the production of strategic level intelligence became a priority. President Franklin D Roosevelt, at the urging of several political advisors, military leaders such as Secretary of the Navy Frank Knox, and British intelligence officer William Stevenson, established the office of the Coordinator of Information (COI) on 11 July 1941, under William Donovan. Donovan was a Wall Street lawyer, World War I hero, and Medal of Honor recipient. ${ }^{36}$ A worldly man, he was approached by Stevenson and asked to solicit Roosevelt regarding the creation of a centralized U.S. intelligence organization. President Roosevelt created the COI and tasked Donovan with the task of consolidating all strategic intelligence and reporting to the President with timely assessments of world affairs. Donovan immediately set to work creating an unprecedented organization to achieve this mission.

\footnotetext{
${ }^{36}$ Douglas Waller, Wild Bill Donovan, The Spymaster Who Created The OSS and Modern American Espionage (New York: Free Press, 2011), 69.
} 
The COI was not without opposition, however. There were many within the established intelligence system who felt the COI would infringe upon their respective operations. Namely, the FBI was afraid that Donovan's organization would disrupt ongoing investigations or encroach upon areas where the FBI already held jurisdiction. ${ }^{37}$ Donovan worked relentlessly to give relevance to the COI, and did so by creating a Research and Analysis Branch (R\&A). Because the COI was tasked with consolidating information from around the intelligence community, various collection reports arrived at COI's headquarters in Foggy Bottom daily, which newly arrived researchers mulled over, and produced reports that Donovan would send to Roosevelt. The men and women who staffed the R\&A Branch where recruited by Donovan from some of the most prestigious east coast schools, with extensive knowledge of foreign culture, language, the classics, economics, and politics. ${ }^{38}$

The COI morphed into the Office of Strategic Services (OSS) in 1942, with an expanded charter that allowed for greater covert action and espionage around the globe. The new office was housed within the Joint Chiefs of Staff in order to allow military oversight of Donovan's organization and alleviate tensions between Donovan and military intelligence commanders. As the war progressed, Roosevelt authorized the OSS to conduct espionage overseas, as well as subversion and sabotage operations. These covert action programs needed to be conducted in cooperation with the military, which illuminates the need for JCS oversight. ${ }^{39}$ Additionally, the OSS did not have total freedom to conduct espionage globally - there were still areas they were denied access, such as Latin America (under the FBI's purview), and much of the Pacific (under the military leadership of General MacArthur). Despite its limitations, the United States finally

\footnotetext{
${ }^{37}$ Waller, Wild Bill Donovan, 70-72.

${ }^{38}$ O'Toole, Honorable Treachery, 438-441 and Waller, Wild Bill Donovan, 77-80.

${ }^{39}$ O'Toole, Honorable Treachery, 490.
} 
had a strategic-minded intelligence institution tasked with providing critical information to the nation's top decision makers.

The OSS was ever changing, and no organizational chart of the outfit lasted for very long before one section or department was moved, changed or eliminated. ${ }^{40}$ The OSS conducted some of the most innovative and daring operations during the war, and set a precedent for a post war intelligence agency. In early 1945, Donovan understood the end of the war was only a matter of time and began looking to the future. The war made it clear in his mind that a regression to pre-1940 intelligence capabilities was an illogical course of action, so Donovan sought to have the OSS given a postwar role. There were critics, however, and unfortunately for Donovan, critics in high places. In late September 1945, President Truman saw no use for the continuation of the OSS and ordered the liquidation of the organization. ${ }^{41}$ There was a move, however, to maintain some of the accumulated resources of the OSS, such that the R\&A Branch was allocated to the Department of State, and the Operations Branch (responsible for espionage and covert action), was moved to the Army. From October 1, 1945 until January 1946, the intelligence structure of the United States had done precisely what Donovan was afraid of: reverted to a prewar model. Truman did task State Department officials to organize a postwar plan for intelligence, but after several months of foot dragging, Truman and his military advisors took charge, and created the Central Intelligence Group (CIG) in January $1946 .{ }^{42}$

The CIG, under the leadership of the newly minted Director of Central Intelligence, Rear Admiral William Leahy, regained control of the R\&A Branch and renamed it the Office of

${ }^{40} \mathrm{O}$ 'Toole, Honorable Treachery, 487-513.

${ }^{41}$ Executive Order 9621, cited in Thomas F Troy, Donovan and the CIA: A History of the Establishment of the Central Intelligence Agency (Frederick, MD: University Publications of America, 1981), 461.

${ }^{42}$ Michael Warner, "Salvation and Liquidation, Creation of the Central Intelligence Group," Center for the Study of Intelligence (August 2011), https://www.cia.gov/library/center-for-the-study-of-intelligence/kentcsi/vol39no5/html/v39i5a13p.htm. (accessed 20 July 2017). The CIG was a stand-alone agency, separate from the Defense Department and State Department, and reported directly to President Truman and his staff. 
Research and Intelligence (ORI), which brought together intelligence products from around the spectrum of collection organizations and once again produced concise reports to help inform senior policymakers, particularly regarding the emerging communist threat from the Soviet Union. ${ }^{43}$ Much like the broadened operational scope that necessitated the formation of the OSS from the COI, expanded operational guidance, in addition to a need to counter communism, led to the establishment of the Central Intelligence Agency (CIA). Tensions between the West and the Communist bloc had reached a boiling point in the late 1940s. The National Security Act of 1947 established several institutions that the president could rely on for strategic level matters. The Act established the National Security Council, which the president used in "formulating and implementing foreign policy." ${ }^{44}$ The Soviet Union tightened its control on East Berlin with a blockade that the West had to overcome with a massive airlift from 1948-1949. ${ }^{45}$ In April of 1950, NSC-68 was drafted by the State Department's Paul Nitze, and was based loosely on an understanding of the bipolar struggle between the U.S. and Soviet Union outlined in George Kennan's "Long Telegram." 46 Although Kennan suggested the Soviet Union would falter under its own systems if contained, Nitze's policy paper added that this could be expedited with "massive military build-up" in addition to containment. ${ }^{47}$ Additionally, for the first time in U.S. history, the National Security Act of 1947 established in law an organization tasked with collecting strategic intelligence for the executive branch and senior policymakers. The CIA inherited many of the personnel who had tirelessly and bravely served during World War II and

\footnotetext{
${ }^{43}$ O'Toole, Honorable Treachery, 517.

${ }^{44}$ Department of State, Office of the Historian "National Security Act of 1947," Milestones: 1945-1952, https://history.state.gov/milestones/1945-1952/national-security-act (accessed 20 July 2017).

45 Department of State, Office of the Historian "The Berlin Airlift, 1948-1949," Milestones: 1945-1952, https://history.state.gov/milestones/1945-1952/berlin-airlift (accessed 20 July 2017).

${ }^{46}$ Department of State, Office of the Historian "NSC-68, 1950," Milestones: 1945-1952, https://history.state.gov/milestones/1945-1952/NSC68 (accessed 20 July 2017).

${ }^{47}$ Office of the Historian "NSC-68, 1950."
} 
the tumultuous early days of the Cold War. This inheritance, coupled with many standards that had been established since the early days of the Second World War would have lasting effects on the CIA's analysis capabilities, well into the 1950s.

The daring, cloak-and-dagger activities of those collecting information - the spiesentice the public and give an intrepid aura to the intelligence field. Ian Fleming's James Bond and numerous other characters in book and film illustrate espionage as exciting and the primary focus of intelligence. Interestingly enough, when the COI was established in 1941, it was solely a report writing entity used by FDR to fill information requirements regarding strategic security issues. Espionage, covert action, and sabotage activities were only added to the purview of the organization once the U.S. became fully engrossed in the War and the office morphed into the OSS. Because of the allure of spies, even amongst the academic community, most literature produced about the IC has been geared towards the exciting tales of espionage and covert action. Except for fictional character Jack Ryan of author Tom Clancy fame, little has been written since the advent of the CIA about the analysts who take the information collected by spies (or other means), and produce the assessments, briefs, estimates, and summaries that actually inform policymakers when they make national security decisions. Even less has been written about the historical contributions of analysts.

When the CIA formed in late 1947, the Office of Research and Estimates (ORE) was the analytic arm of the agency. The ORE created several intelligence products for top policymakers, including the Daily and Weekly summaries and the Review of the World Situation. Dating back to the $\mathrm{CIG}$, the president required a concise and cooperative estimate from the intelligence community regarding foreign matters of strategic and national security value. The Director of Central Intelligence was responsible for organizing the coalescing of this information into 
National Intelligence Estimates (NIEs), which were assessments based on intelligence available to each organizational intelligence agency as well as the CIA's ORE. A majority judgement was agreed upon for final draft production, with an addendum following in an appendix explaining any minority judgments. The many varieties of reports drafted by the CIA are noted in a memo sent from Assistant Director of Current Intelligence Huntington Sheldon to NSC Executive Secretary James Lay in January 1953 regarding the latter's request for information on the types of reports available to policymakers. Sheldon outlines the daily, weekly, and irregular publications, NIEs being included in the latter. ${ }^{48}$

As Cold War tensions grew and hostilities on the Korean peninsula developed in the late 1940s, ORE incorrectly assessed the intent of the North Koreans. In spring 1950, ORE report 1850, Current Capabilities of the Northern Korean Regime, shows that analysts did not expect North Korea to act unilaterally, opining that Moscow had hegemonic control over the actions of satellite communist states. On June 25, 1950, North Korean military forces crossed the 38th parallel and drove south with the intent of uniting the Korean peninsula under communist rule. CIA analysts were aware of the potential North Korea had to conduct such an operation, and had assets in place reporting on troop movement and build up near the border with capitalist South Korea, but assessed an incursion was unlikely. ${ }^{49}$ This proved a dramatic misstep by ORE. When the North Korean People's Army crossed the $38^{\text {th }}$ parallel, the CIA, President Truman, and the world were taken by surprise ${ }^{50}$ Later that year, the DCI was directed to produce an estimate of

\footnotetext{
${ }^{48}$ National Security Council, Memo for James Lay from Asst. Dir. Current Intelligence Huntington Sheldon, 21 January 1953. White House Office, National Security Council Staff, Papers 48-61, NSC Registry Series, Box 3, Eisenhower Library, Abilene, Kansas.

${ }^{49}$ Stanley Weintraub, MacArthur's War, Korea and the Undoing of an American Hero (New York: Simon \& Schuster, 2008), 1.

${ }^{50}$ Center for the Study of Intelligence, Baptism by fire: CIA Analysis of the Korean War, A Collection of Previously Released and Recently Declassified Intelligence Documents (North Charleston: CreateSpace Publishing, 2014),9.
} 
Soviet Capabilities and Intentions, which the CIA did in cooperation with the IC in November 1950, entitled NIE-3, Soviet Capabilities and Intentions. This estimate made a critical misjudgment as well-one of which led to the second surprise of 1950 - the Chinese involvement in the Korea War, launched in late November. In NIE-3, there was no indication that China was an independent actor, and while not overtly stating it, the estimate credits the Kremlin with monolithic control of global communism. NIE-3 had no indication that China would have its own reasons to attack into North Korea. As General Douglas MacArthur's troops drove North Korean troops northward, the Chinese People's Liberation Army crossed the Yalu River to aid North Korea, tendering a second strategic surprise to the U.S. and CIA. ${ }^{51}$ Because of the advent of Soviet atomic weapons the year prior, the increased hostility in Korea, China, and Eastern Europe, and the uncertainty of communist intentions in Latin America, containment policy and U.S. efforts to subvert communism had reached a critical point in late 1950. NIE-3 is clear evidence of this.

Intelligence failure is a highly studied topic and an extensive collection of scholarship exists examining and theorizing the root causes of failure. Dr. Erik Dahl proposes failure is the result of a lack of precise tactical level information accompanied by a lack of receptivity from decision makers. His work, Intelligence and Surprise Attack: Failure and Success from Pearl Harbor to 9/11 and Beyond, assesses the many intelligence failure theories that exist, from scholars like Roberta Wohlstetter and Richard Betts, to more contemporary (and often contrarian) theorizers. ${ }^{52}$ Roger George, National Security Strategy Professor at the National War

\footnotetext{
${ }^{51}$ Center for the Study of Intelligence, Baptism by fire, 22.

52 Roberta Wohlstetter's narrative, Pearl Harbor: Warning and Decision (Stanford: Stanford University Press, 1962), is regarded by most contemporary intelligence scholars as one of the most logical theory behind the Japanese surprise attack on Pearl Harbor. Her narrative suggests that the US had the information it needed to deduce the impending attack, but that information was spread out between various fleet intelligence units and organizational intelligence agencies back in Washington. Furthermore, there were two additional
} 
College and former CIA analyst, notes that a surplus of literature has recently emerged capturing "intelligence-failures" and suggests this literature is largely based on "gotcha" or "connect the dots" mentalities which blame intelligence professionals (analysts) for national security surprises. ${ }^{53}$ George reviewed The CIA and the Culture of Failure by John Diamond, one of these emergent narratives, and offers accolades because Diamond, unlike many of his contemporaries, does not try to blame "alleged CIA incompetence" for many recent intelligence failures. Instead, Diamond suggests that an "atmosphere of declining confidence" in the IC has lead policymakers to form conclusions largely independent of analytic intelligence products, both in 1950 and currently. In the wake of Korean War intelligence failures, Diamond's thesis-while only one of many leading arguments-lays the foundation for reexamining the early relationship between CIA's analytic arm and the White House.

From late 1947 to late 1950 the IC produced very little reporting of immediate concern on Latin America. The focus, with understandable reason, had shifted to eastern Europe and the western Pacific, and NIE-3 has no mention at all of Latin America or Soviet intentions in Latin America. This indicates a slight shift in analytic priorities, one where information of strategic value (forecasting judgments) was often placed on the back-burner to ensure operational or even tactical intelligence was not neglected, thus opening the door for further strategic surprise. However, as a result of the miscalculations in 1950, the CIA, now under new leadership from

complications - first, there was no one trained to consolidate intelligence from multiple sources and analyze that data for a value-added product; and second, there was an over-abundance of collected information (decrypted diplomatic and naval radio transmissions, known enemy espionage collection at Pearl Harbor, and diplomatic warning from other embassy's) such that even if there were an "all-source" analyst reviewing the various intelligence sources, he or she would not have been able to quickly sort the wheat from the chaff.

${ }^{53}$ Roger Z. George reviewing John Diamond, The CIA and the Culture of Failure: US Intelligence from the End of the Cold War (Stanford: Stanford University Press, 2008), 536 p., for Intelligence in Public Literature, (21 April 2009), https://www.cia.gov/library/center-for-the-study-of-intelligence/csi-publications/csistudies/studies/vol53no1/the-cia-and-the-culture-of-failure-u.s..html (accessed 20 July 2017). 
General Walter B. Smith, sought to revamp the ORE in order to avoid additional analytic errors. $^{54}$

\section{US COLD WAR POLICY: NSC 68 VS THE NEW LOOK}

In August 1949 the Soviet Union tested its first atomic weapon, which was detected by sensors on U.S. military aircraft on patrol off the Soviet border. Not even a year later, amid growing fears of Soviet intentions and "hostile designs" the State Department drafted NSC-68 for the Truman administration. This policy paper suggested "the Soviet threat would soon be greatly augmented by the addition of more weapons, including nuclear weapons... [and] the best course of action was to respond in kind with a massive build-up of the U.S. military and its weaponry." 55 Following Truman's administration, whose anti-communist policy outlined and established the "containment" strategy in NSC-68, President Eisenhower opted for a different approach. Meeting with his staff in discussions codenamed Project Solarium, Eisenhower and his top Cabinet members and key advisors developed NSC 162/2, better known as the "New Look" policy. ${ }^{56}$ Among those who sat at these meeting was George Kennan of the State Department, architect of the containment doctrine. As part of the policy of containment the U.S. sought (as did the Soviet Union) to avoid general war-especially after U.S. reconnaissance aircraft detected radioactive isotopes in the atmosphere of the North Pacific, indicating the insidious reality that the Soviet Union had developed an atomic weapon. Under Kennan's plan, the Soviet

\footnotetext{
${ }^{54}$ Central Intelligence Agency, Office of Reports \& Estimates, "Soviet Capabilities and Intentions," National Intelligence Estimate (NIE) 3, (15 Nov 1950), https://www.cia.gov/library/readingroom/document/ciardp86b00269r000300040009-5 (accessed 21 July 2017).

${ }^{55}$ Office of the Historian "NSC-68, 1950."

${ }^{56}$ Foreign Relations of the United States, 1952-1954, National Security Affairs, Volume II, Part 1, Document 101, NSC 162/2, "Note by the Executive Secretary to the National Security Council on Basic National Security Policy," eds. Lisle Rose, Neal Petersen, and William Slany (Washington: Government Printing Office, 1984), https://history.state.gov/historicaldocuments/frus1952-54v02p1/d101 (accessed 21 July 2017).
} 
Union and communism would collapse under its own ill-conceived plans if the U.S. simply prevented it from expanding to new areas. This report, sent via telegram from Kennan's post in Moscow to the Secretary of State, became known as the "long telegram" and set the stage for U.S. policy and intelligence operations under Truman's administration. ${ }^{57}$ A key component of Truman's foreign policy, as outlined in NSC-68, included the rapid growth of the military as a deterrent to Soviet aggression and expansion. However, having first hand observed the complexities of outright war and what a gradual crescendo of military strength might do to the global environment, Eisenhower was not keen on the continued expansion of the U.S. military. Eisenhower's farewell address in January 1961 is often referred to as the "military industrial complex" speech, due to his cautious remarks regarding the growth of an ostensibly unchecked military. Yet within Eisenhower's administration there existed a dichotomy of opinion on how best to proceed - continue to contain communism, attempt to roll it back, or devise another strategy. Eisenhower's intention with Project Solarium was to unite his administration under a common strategy. The resulting policy, the "New Look," accomplished that.

President Eisenhower felt that "massive retaliation" should be the method of reprisal if communists attacked the interests of the U.S. using atomic weapons. In order to do so, an arms race emerged between the U.S. and USSR, each attempting to keep abreast of the other's arsenal. Early in NSC 162/2, drafted by James Lay (NSC's Executive Secretary), it is recognized and addressed that containment may not be adequate to ensure Soviet pressure would remain unable to threaten the "fundamental values and institutions" of the United States and that the primary threats were Soviet hostility towards the non-communist world, its great military power, and control of the international communist apparatus by means of subversion or division of the free

\footnotetext{
${ }^{57}$ Department of State, Office of the Historian "George Kennan and Containment," A Short History of The Department of State, https://history.state.gov/departmenthistory/short-history/kennan (accessed 20 July 2017).
} 
world. ${ }^{58}$ This, however, is no major deviation from the status quo of world affairs since the conclusion of World War II, nor had the outlook changed much since the Soviets acquired nuclear weapons or Stalin's death. What was different, as noted by Lay, was that the rolling back of communism was not expected to be possible. "The detachment of any major European satellite from the Soviet bloc does not now appear feasible except by Soviet acquiescence or by war," suggesting that a stalemate was present and a reevaluation of policy was needed. ${ }^{59}$ War was "improbable" since Soviet victory was assessed to be unlikely in a conflict. "Atomic plenty," i.e. both the U.S. and USSR amassing enough atomic weapons to effectively annihilate the opposition, would "create a stalemate, with both sides reluctant to initiate general warfare," but Lay also notes that if an atomic strike was launched, major atomic retaliation would be almost certain. ${ }^{60}$ This all understood, Eisenhower decided to seek alternative policy suggestions. What emerged were the Solarium talks and the "New Look."

The "New Look" was not vastly different from Truman's strategy of containment which wanted massive military build-up to counter Soviet aggression. As a matter of fact, it was largely an extension of it, albeit with a different focus on spending. Truman, a fan of a large standing military to counter massive Soviet military manpower, preferred to develop conventional forces. After Eisenhower's staff evaluated the geopolitical situation of the early 1950s, they recognized a need to improve the economic growth of the United States, identified a need for limited military spending and greater dependence on unconventional-covert and atomic-means to achieve victory, and the "New Look" became the foundation of these strategic policies.

\footnotetext{
${ }^{58}$ NSC 162/2, "Note by the Executive Secretary to the National Security Council on Basic National Security Policy," 579, which outlines the basic problems of national security policy as well as defining the soviet threat to the U.S.

${ }^{59}$ NSC 162/2, "Note by the Executive Secretary to the National Security Council on Basic National Security Policy," 581.

${ }^{60}$ NSC 162/2, "Note by the Executive Secretary to the National Security Council on Basic National Security Policy," 582.
} 
Eisenhower could achieve more with less with the "New Look." To defend against Soviet power and action, the U.S. "must develop and maintain, at the lowest feasible cost, the requisite military and non-military strength to deter and, if necessary, to counter Soviet military aggression against the United States or other areas vital to its security." ${ }^{\prime \prime 1}$ The "non-military" strength specifically mentioned in NSC 162/2 was a security posture supported by an "effective intelligence system." ${ }^{, 62}$ Allen Dulles and the CIA had official policy supporting their greater relevance in countering communism.

NSC 162/2 also sought to establish other strategic policies aimed at reducing military spending while simultaneously stabilizing and improving domestic conditions. To remain safe, the U.S. needed to have striking power forward deployed at allied bases in case retaliation was necessary. Major alliances, therefore, had to be maintained. Furthermore, allies must know that the strategy is one of collective security against communism. ${ }^{63}$ The major difference, as articulated in NSC 162/2, between the "New Look" and the Truman Doctrine is apparent with the comment that "in the event of hostilities, the United States will consider nuclear weapons to be as available for use as other munitions." Ike and his NSC felt that nuclear weapons had just as much weight, or more, as conventional weapons. Yet they did not trust the general population to understand this sentiment. This previous comment is followed with: "This policy should not be made public without further consideration by the National Security Council." ${ }^{64}$ A strong U.S. economy was defined within NSC $162 / 2$ as crucial to maintaining the security and stability of the

\footnotetext{
${ }^{61}$ NSC 162/2, "Note by the Executive Secretary to the National Security Council on Basic National Security Policy," 583.

${ }^{62}$ NSC 162/2, "Note by the Executive Secretary to the National Security Council on Basic National Security Policy," 583.

${ }^{63}$ NSC 162/2, "Note by the Executive Secretary to the National Security Council on Basic National Security Policy," 585.

${ }^{64}$ NSC 162/2, "Note by the Executive Secretary to the National Security Council on Basic National Security Policy," 594.
} 
free world. "Defense expenditures should not seriously impair the basic soundness of the U.S. economy by undermining incentives or by inflation." ${ }^{65}$ Finally, Eisenhower's staff agreed that it should prepare for the worst, yet hope for the best. As the policy paper concludes, it emphasizes that creating "atomic plenty" in order to be able to "massively retaliate" against communist aggression should be the goal, yet while this growth of power is taking place, all means possible to establish diplomatic ties for "[negotiating] for alleviation under proper safeguards" should be attempted. ${ }^{66}$

\section{U.S. COVERT ACTION}

As Supreme Allied Commander of the Allied Expeditionary Forces in Europe during World War II, Eisenhower not only commanded conventional military forces, but also those of a more clandestine and covert nature. During the lead up to the Normandy invasion, Eisenhower participated in the planning, coordination with, and deployment of commandos whose responsibility would be to lead guerilla forces behind French and Belgian lines. Eisenhower faced diplomatic complications in London and Washington, as non-recognition of Free French leader Charles de Gaulle inhibited his ability to launch these commando teams when he wanted. However, after working with Donovan's OSS and British SOE and gaining perspective on the effectiveness of covert operations and espionage, Eisenhower solidified his understanding of the utility these commandos provided. Historian Benjamin Jones noted that Eisenhower and his planners drew inspiration from T.E. Lawrence and General Edmund Allenby's Arab operations

\footnotetext{
${ }^{65}$ NSC 162/2, "Note by the Executive Secretary to the National Security Council on Basic National Security Policy," 594.

${ }^{66}$ NSC 162/2, "Note by the Executive Secretary to the National Security Council on Basic National Security Policy," 596.
} 
in the First World War, and that coupling new technology with similar conventional and insurgent tactics would be highly effective against the Reich. ${ }^{67}$

Covert action, not originally part of the CIA's charter, became a function of the Central Intelligence Agency in the late 1940s. Collection and Analysis were the two major responsibilities of the Agency, but it became apparent that within the realm of secret operations, covert action might be a necessary additional task. Intelligence collection can be either covert or overt. Overt collection by persons assigned to such roles is the foundation of those in the Defense Attaché Office within the Department of Defense. Nations around the globe have long exchanged military officers to study and report what their military counterparts are doing abroad with the intent of using that information to keep apace of foreign peers and rivals. Oppositely, covert collection (traditional espionage), is clandestine for the sake of protecting the asset that is providing information to a collections officer. While clandestine in nature, the primary focus is not to hide the hand of the country doing the collection, but rather the identities of those involved in the espionage. Covert action, however, is entirely clandestine and designed to completely hide the hand of the nation authorizing the activity. As historian Evan Thomas notes in The Very Best Men, covert action is that "dirty work" governments undertake without attaching blame to the leadership authorizing that action, i.e. "plausible deniability." ${ }^{68}$ Covert action goes well beyond collecting information - it is "undertaken in other countries to accomplish a U.S. foreign policy objective without the hand of the U.S. government becoming known or apparent to the outside world." 69

\footnotetext{
${ }^{67}$ Benjamin F Jones, Eisenhower's Guerrillas, The Jedburghs, The Maquis, \& The Liberation of France (Oxford: Oxford University Press, 2016), 1-3.

${ }^{68}$ Evan Thomas, The Very Best Men: The Daring Early Years of the CIA (New York: Simon \& Schuster, 2006), 28.

${ }^{69}$ Central Intelligence Agency, "Oversight of Covert Action," Center for the Study of Intelligence, https://www.cia.gov/library/center-for-the-study-of-intelligence/csi-publications/books-and-
} 
The "New Look" policy, discussed above, lends itself to the use of covert action as an extension of policy by other means. ${ }^{70}$ Many scholars have suggested that President Eisenhower had a proclivity for the clandestine and covert after his experiences in World War II and as a result of early Cold War covert action successes. The first such action, undertaken during the Truman administration, was a prime example of the U.S. government's hidden hand influencing foreign policy to the benefit of the United States. CIA's Office of Special Operations (OSO), an OSS relic that was predominantly collections oriented, used political covert action to influence the 1948 elections in Italy. It was assessed that Moscow was funneling so much money into propaganda efforts in Italy that the communist party would undoubtedly win the elections. This, as it turned out, was incorrect but OSO nevertheless infused millions into the accounts of rightwing parties effectively shutting down any communist chance for success. This political action success set the stage for the creation of an official covert action arm within the U.S. government, one solely dedicated to covert action and separate from traditional espionage. Drafted by George Kennan of the State Department, NSC memorandum 10/2 established the Office of Policy Coordination (OPC) and housed it with CIA. ${ }^{71}$

The second instance was a plan discussed and tabled during the Truman administration and executed early on in Eisenhower's first term. Iranian leader Mohammed Mossadegh, who outwardly appeared to have close ties with Moscow, nationalized the British Anglo-Iranian Oil Company (AIOC), raising concerns that Iran could fall to communism. British intelligence, unable to work within Iranian borders after AIOC was nationalized, sought American help to overthrow the Iranian regime and install a pro-West government. Kermit Roosevelt (grandson of

\footnotetext{
monographs/agency-and-the-hill/12-The\%20Agency\%20and\%20the\%20Hill_Part2-Chapter9.pdf., 261 (accessed 20July 2017).

${ }^{70}$ Carl von Clausewitz' On War suggests that war as an extension of policy but by other means.

${ }^{71}$ Thomas, The Very Best Men, 28-29.
} 
President Theodore Roosevelt) of the CIA led a propaganda operation against Mossadegh in order to stage a coup. Roosevelt succeeded with what the White House perceived as relative ease. The pro-West Shah assumed control of the country and Mossadegh was arrested. Eisenhower wrote in his diary on 8 October, 1953 that "if the Shah...will be only a little bit flexible... we may really give a serious defeat to the Russian intentions and plans in that area," 72 demonstrating the satisfaction in a job well done, and for the specific purpose of restraining Soviet expansion. To Eisenhower, installing a pro-West leader was not the agenda. Countering communism in any area and leaving the smallest footprint while doing so was the critical task at hand. Though dramatically destabilized and polarized, Iran was viewed as a covert action success, suggesting that such methods may be ideal when diplomacy fails and conventional military action is too costly. ${ }^{73}$

\footnotetext{
${ }^{72}$ Dwight D. Eisenhower, Mandate for Change, 1953-1956 (Garden City, New York: Doubleday, 1963), 166.

${ }^{73}$ Central Intelligence Agency, "Oversight of Covert Action," 261-263.
} 


\section{CHAPTER 2: PBSUCESS AND EISENHOWER}

\section{THE PATH TO OPERATION PBSUCCESS}

The atmosphere of anxiety in the United States caused by fear of communism is not unfamiliar to students of U.S. history. President Eisenhower, in a personal memo to the Attorney General in November 1953, offered understanding and bipartisanship to leftists within the U.S. and U.S. government, recognizing that the Soviets were allies during World War II. As such, many U.S. citizens, at one point, spoke favorably about the Soviets. However, Eisenhower found Americans who still harbored such sympathies after the "blockade of Berlin began," to be "stupid or very dangerous." ${ }^{74}$ Ike's olive branch to the left was now contingent on recognizing the USSR as a rival. CIA reports from the early 1950s also demonstrated this fear. Historian Nick Cullather, author of Secret History: The CIA's Classified Account of Its Operations in Guatemala, 1952-1954, relating fear of communism with the situation in Guatemala, stated that these fears "were not manifestations of McCarthyite paranoia but a fear shared by liberals and conservatives, academics, journalists, and government officials, that a Soviet conspiracy [existed] aimed to strike at America in its own backyard." 75 The "red scare," in essence, affected nearly all Americans. Many in the Eisenhower government also felt that Moscow had a nefarious hidden hand and controlled communist sympathizers around the globe. U.S. Ambassador to Guatemala, John Peurifoy, stated that "Communism is directed by the Kremlin all over the world, and anyone who thinks differently doesn't know what he is talking about." 76

In March 1952 the CIA's Office of National Estimates published an estimative, or predictive, assessment entitled "Present situation in Guatemala and Possible Developments

\footnotetext{
${ }^{74}$ Memorandum for the Attorney General from President Dwight Eisenhower, 4 Nov 1953, Ann Whitman File, DDE Diary Series, Eisenhower Library, Abilene, Kansas.

${ }^{75}$ Cullather, Secret History, 27.

${ }^{76}$ Cullather, Secret History 26, and House Select Committee on Communist Aggression, Communist Aggression in Latin America, 83rd Cong., 2d sess., 1954, p. 125.
} 
During 1952," which outlined what agency officials believed to be a bleak future under President Árbenz' administration. In June 1952, Decree 900, or the Agrarian Reform Law, introduced and championed by Árbenz, passed in the Guatemalan Congress. An effort to give the rural peasantry the ability to farm for subsistence and contribute excess produce to local markets, the reform plan was praised by the PGT, alarming Washington. The agrarian land reform, despite its emphasis on the potential capitalist advancement of a larger portion of Guatemala's population, was seen as a "potential opening for the radicalization of Guatemala. Communists would use land redistribution 'to mobilize the hitherto inert mass of rural workers." ${ }^{77}$ The plan called for the redistribution of land on estates larger than 223 acres in which more than two thirds of the land was uncultivated. The acquired land would be given to hundreds of thousands of peasant families. The expropriation of land was not without compensation to the estate holder, however. Further, estates under federal jurisdiction were also subject to and included in the redistribution plan. The decree sought to "develop the land to the form of operational and capitalist methods of production in agriculture and to prepare the way for the industrialization of Guatemala." 78 Historically dependent on the U.S. for manufactured materials, leaders in Guatemala City posited nationalistic advancement would require gradual industrialization and eventual liberation from the need for U.S. goods. ${ }^{79}$ Nationalism in Guatemala, especially after Soviet development of

\footnotetext{
${ }^{77}$ Cullather, Secret History, 23 and Gleijeses, Shattered Hope, 164. Board of National Estimates to the Intelligence Advisory Committee, NIE- 84: Probably Developments in Guatemala (8 May 1953), https://www.cia.gov/library/readingroom/document/0000914889 (accessed 21 July 2017).

${ }^{78}$ Tiffany K Harbor, Creating a New Guatemala: The 1952 Agrarian Reform Law (Dayton: Wright State University, 2008), 28. Decree translated and discussed by Harbor as part of her master's thesis.

${ }^{79}$ Office of National Estimates, "NIE-99 Estimate of the World Situation through 1955," National Intelligence Estimate (5 Sept 1953), https://www.cia.gov/library/readingroom/document/0000039792 (accessed 21 July 2017), written by CIA's Office of National Estimates states "This change results from forced industrialization at the expense of agriculture, which is generally accompanied by severe inflation. Right or left extremism which poses potential threats to US security interests will probably be strongest in Argentina, Bolivia, Chile, Guatemala, and possibly Brazil. In these countries there will continue to be substantial Communist and demagogic nationalist influences, which will attempt to channel the resentment of the dislocated groups against the US."
} 
nuclear weapons intensified the red scare within the U.S., became tantamount with communism, with State Department officials suggesting a deeper concern "because the Communists have been able to distort this spirit to serve their own ends." ${ }^{80}$ However, in seizing land for redistribution, the Árbenz administration targeted a dangerous foe-Boston based United Fruit Company. In 1952, the company lost 234,000 out of 295,000 acres at its Tiquisate plantation, and in 1954 , it lost 173,000 out of 253,000 acres at its Bananera plantation. Compensation for the expropriated land was offered by the Guatemalan government, but was considered inadequate by the fruit company, as well as the U.S. government. ${ }^{81}$ The Guatemalan government appraised the value of the land at just over one million dollars, while United Fruit, accustom to undervaluing the land's actual worth on past tax documents, calculated the land at just over nineteen million dollars, which historian Piero Gleijeses notes was "steadfastly endorsed by the [U.S.] State Department." $" 82$

NIE 62, discussed in more detail below, assessed that Guatemalan communists enjoyed a growing position of power under Árbenz and that the situation would become even more untenable for anti-communists in the months and years which remained in Árbenz' administration. As conditions grew worse for the United Fruit Company, and anxiety about a possible communist beachhead in the hemisphere grew, CIA officials began contemplating a covert plan to topple Árbenz. NIE 62 discussed the various anti-communist actors in Guatemala - the Catholic Church, the landed elite, the Army, and United Fruit-but noted that there was a lack of coordination to oppose the growing communist threat. CIA planners sought to

\footnotetext{
${ }^{80}$ Cullather, Secret History, 15 and Foreign Relations of the United States, 1951, The United Nations; The Western Hemisphere, Volume II, 1419, eds. Ralph Goodwin, N. Stephen Kane, and Harriet Schwar (Washington: Government Printing Office, 1979), Document 800, https://history.state.gov/historicaldocuments/frus1951v02/d800 (accessed 20 July 2017).

${ }^{81}$ Richard Immerman, The CIA in Guatemala: The Foreign Policy of Intervention, (Austin: University of Texas Press, 1982), 81.

${ }^{82}$ Gleijeses, Shattered Hope, 164.
} 
organize anti-communists and find a figurehead to lead a coup against the Árbenz administration. CIA covert planners, after meeting with rebel leader Castillo Armas, surmised that with or without U.S. "money, arms, aircraft, and boats" a rebel attack from either Mexico, Honduras, or El Salvador would likely still take place. ${ }^{83}$ After coordination between CIA director Walter Bedell Smith and Under Secretary of State David Bruce, State department officials stated they "wanted a new government in Guatemala imposed by force if necessary," and Operation PBFORTUNE was approved in September $1952 .{ }^{84}$ However, before the operation could even take off, Secretary of State Dean Acheson requested it be terminated after rumors of the plan leaked throughout Central America after other pro-U.S. governments involved in the operation's planning prattled about it. Secretary Acheson was more concerned with maintaining the fidelity of the 1947 Rio Pact, a non-intervention pledge agreed upon during the establishment of the Organization of American States (OAS) ${ }^{85}$ With little fanfare, PBFORTUNE was placed on hold by Western Hemisphere planners with the hopes that the newly elected Dwight Eisenhower would be more receptive to their covert action agenda. ${ }^{86}$

By the summer of 1953, the situation in Guatemala seemed to continue spiraling out of control in favor of local communists. A failed anti-communist attack at Salama in March resulted in the jailing of nearly all useful assets the CIA had in place, further complicating the objectives

\footnotetext{
${ }^{83}$ Cullather, Secret History, 29.

${ }^{84}$ Cullather, Secret History, 29.

${ }^{85}$ Cullather, Secret History, 31.

${ }^{86}$ Garry Clifford, "Bureaucratic Politics" in Explaining the History of American Foreign Relations, ed. Michael Hogan and Thomas Paterson (Cambridge: Cambridge University Press, 2004), 91. In using bureaucratic politics as a framework of historical analysis and interpretation, the course of action taken by both the State Department and CIA to place PBFORTUNE plans on hold in hopes of a new administration approving the operation demonstrates that organizations have agendas and core values, and they are not always perfectly in line with the national core values and objectives. While opposing communism in favor of the advancement of capitalism and western ideals is a common core value of the Cold War U.S. strategy, there were many throughout the government, Secretary Dean Acheson for example, who opposed covert action as a means of furthering U.S. policy.
} 
of Agency planners. ${ }^{87}$ However, with the advent of the "New Look" policy, discussed in the previous chapter, the Eisenhower administration poised itself to carry out its most audacious covert action to date. On 12 August 1953 the National Security Council, after reviewing key intelligence assessments, determined that covert action aimed at the overthrow of Árbenz must occur to keep communist control in Guatemala from growing. As Cullather notes, PBSUCCESS as it would be known, would be the most complex covert action taken to date, and would "combine psychological, economic, diplomatic, and paramilitary action." $\$ 88$ The unity of effort within the government was paramount-CIA and State would work simultaneously to discredit and depose Árbenz. However, the organizational agendas that began in the Truman administration continued into Eisenhower's first term, and almost certainly influenced Ike's decision making process, which will be discussed further in chapter three. Growing anxiety throughout 1953 and early 1954, specifically with the secret shipment of arms from Czechoslovakia aboard the Alfhem, and discussions between OAS members, sealed Guatemala's fate. After months of planning, on 18 June 1954, forces under the command of Castillo Armas crossed the border from several staging points in El Salvador and Honduras and began their invasion of Guatemala. Bolstered by CIA propaganda radio transmissions and air support, as well as unforeseen morale complications within the Guatemalan Army, the rebels were able to force Árbenz' resignation in just under two weeks.

\section{CIA ASSESSMENTS}

Before investigating those analytic products which were essential to policymakers in Eisenhower's administration, it is important to review what CIA was producing and for whom,

\footnotetext{
${ }^{87}$ Cullather, Secret History, 33-35.

${ }^{88}$ Cullather, Secret History, 35-40.
} 
as well as discuss who was actually performing the analysis and production. CIA created a number of assessments for a variety of customers. For someone new to the workings of intelligence, this can seem overwhelming. For example, James Lay, Executive Secretary of the National Security Council, asked the Assistant Director for Current Intelligence, Huntington Sheldon, for a memo detailing a list of CIA publications in early January, 1953 while trying to grasp the scope of production at CIA ${ }^{89}$ On the 21 st, Sheldon replied with the following list:

\begin{tabular}{|c|c|}
\hline \multicolumn{2}{|c|}{ Daily } \\
\hline Product Title & Classification \\
\hline *Current Intelligence Bulletin & TS Codeword \\
\hline *Current Intelligence Digest & $\mathrm{S}$ \\
\hline *Current Intelligence Digest (TS Supplement) & TS \\
\hline $\begin{array}{c}* \text { Current Intelligence Digest (Special } \\
\text { Supplement) }\end{array}$ & TS Codeword \\
\hline$*$ Daily Korean Bulletin & $\mathrm{S}$ \\
\hline FBIS Daily Report & UN-R-C (Selected Foreign Radio Broadcasts) \\
\hline \multicolumn{2}{|r|}{ Weekly } \\
\hline *Current Intelligence Review & TS Codeword \\
\hline$*$ Situation Summary & TS Codeword \\
\hline *DCI Weekly Cable Summary & $\begin{array}{l}\text { TS- Eyes Only (selected Sensitive State Dept. } \\
\text { Cables) }\end{array}$ \\
\hline \multicolumn{2}{|r|}{ Irregular } \\
\hline $\begin{array}{l}\text { National Intelligence Surveys (Basic } \\
\text { Intelligence "Handbook") }\end{array}$ & $\mathrm{S}$ and TS \\
\hline $\begin{array}{l}\text { National Intelligence Estimates (fully } \\
\text { coordinated within IAC) }\end{array}$ & TS \\
\hline $\begin{array}{l}\text { Special Intelligence Estimates (fully } \\
\text { coordinated within IAC) }\end{array}$ & TS Codeword \\
\hline Special Estimates & TS \\
\hline
\end{tabular}

This list showed that a significant number of products came from the Office of Current Intelligence (OCI). It also raises the question: what is current intelligence, and what other types of intelligence are there?

\footnotetext{
${ }^{89}$ Memo for James Lay from Ass. Dir. Current Intelligence Huntington Sheldon, 21 January 1953. White House Office, National Security Council Staff, Papers 48-61, NSC Registry Series, Box 3, Eisenhower Library, Abilene, Kansas.
} 
Historians for the CIA's Center for the Study of Intelligence wrote that, as a result of the intelligence failures that plagued the Agency at the start of the Korean War, CIA underwent a drastic reorganization — both operationally and analytically. Walter Bedell Smith was brought in to lead the Agency and rallied experts, like Sherman Kent, to assist in improving functionality. In late October 1950, Smith attended a meeting with the Intelligence Advisory Committee (IAC; established to provide guidance to the Agency, "intended... as the principal forum for discussing interagency problems, and jurisdictional conflicts, and as the final review committee for national intelligence estimates" 90 ) and defined the "primary responsibility [of the CIA is] insuring that surprise or intelligence failure did not jeopardize national security—as happened at Pearl Harbor or with the outbreak of the Korean War." ${ }^{91}$ One of the first things Smith did was establish a new home for the production of National Intelligence estimates - the Office of National Estimates (ONE). Walter Langer, a former OSS R\&A Branch member, was appointed to lead ONE and maintained the office as a very small component of senior and experienced analysts. Over the course of the next year, Smith also created the Deputy Directorate of Intelligence (DI), and by January of 1952, the DI consisted of six offices with different foci of effort. The Office of National Estimates produced top-level strategic estimates; the Office of Research and Reports (ORR) handled mid-level and basic intelligence that required traditional topical study versus analysis and ORR products sometimes offered potential policy commentary; the Office of Scientific Intelligence, dedicated to technical analysis of operational and strategic subjects; the Office of Current Intelligence, who produced daily, top-level summary reports to keep policymakers appraised on flash news; the Office of Collection and Dissemination, working to

\footnotetext{
${ }^{90}$ Clayton Laurie, "The Korean War and the Central Intelligence Agency," Center for the Study of Intelligence (2010), 5, https://www.cia.gov/library/readingroom/docs/2010-05-01.pdf (accessed 20 July 2017). ${ }^{91}$ Historical Collections Division, Central Intelligence Agency, Baptism by Fire, CIA Analysis of the Korean War: A collection of Previously Release and Recently Declassified Intelligence Documents (CIA Center for the Study of Intelligence, 2013), 15.
} 
coordinate incoming information and outgoing final intelligence; and the Office of Intelligence Coordination, who networked with other intelligence disciplines and agencies to ensure a thorough product line. The Office of National Estimates and Office of Current Intelligence were the two sections that produced the critical assessments which made it most often to high-level policymakers and who drafted daily, weekly, and irregular assessments that helped inform decisions. ${ }^{92}$ The following sections will look at the National Intelligence Estimates and Current Intelligence Bulletins produced for the National Security Council and Eisenhower's staff. ONE products and OCI products fit into two categories of intelligence: current and estimative. The first section will discuss estimative intelligence and demonstrate what ONE analysts - senior and experienced professionals within the DI-anticipated what was likely to happen in Guatemala and will explore this from 1950 until the overthrow of Árbenz. The OCI products, the current intelligence, are akin to journalistic writing, albeit with a different, often clandestine, set of sources and with a different clientele. OCI products reviewed will cover from the agrarian reform law in 1952 until the end of Operation PBSUCCESS in the summer of 1954. These products offer the clearest view of what analysts at CIA knew about the events taking place in Guatemala and by studying their assessments, the policy making decision processes will become more apparent. These products were read by the highest level policymakers: the NSC, CIA director, Directors and Deputy Directors of State, Defense, and other strategic departments. During meetings and in their official (and sometimes unofficial) correspondence, these top officials used CIA assessments to frame issues for discussion. ONE and OCI analysts did an effective job framing the problem in Guatemala for these policymakers, and a study of their work follows below.

\footnotetext{
${ }^{92}$ Historical Collections Division, Central Intelligence Agency, Baptism by Fire, 16.
} 


\section{OFFICE OF NATIONAL ESTIMATES}

From early 1950 through mid-1953 ONE analysts drafted several NIEs and other specialty products to aid in situational prediction in Guatemala. Their aim, to reduce uncertainty for policy makers in Eisenhower's Cabinet, was clearly articulated in the many assessments that made it through the IAC and into the hands of top officials. Additionally, going as far back as CIG and ORE analysts, critical finished intelligence was provided to Truman's administration regarding Soviet intentions in Latin America. In April 1947, the CIG predicted a dire outlook in Latin America, though not so ominous as to require immediate action. Principally, CIG ORE 16 suggested that Latin America was simply not worth the Soviet's efforts, politically or in terms of developing significant economic ties. ${ }^{93}$ This report, one of the first produced by the CIG, stated that if a war were to erupt between the U.S. and USSR, a U.S. blockade would easily prevent resources from getting to or leaving Latin America, making Soviet territorial acquisition less likely to be the immediate goal of Soviet communism. ${ }^{94}$ Additionally, because of the expectation of a U.S. blockade, ORE suggested there would be no reason for the USSR to build an extensive trade relationship with Latin America since it would be cut off if general war broke out. ${ }^{95}$ Furthermore, analysts suggested that the Soviets were most fearful of the establishment of a hemisphere defense pact, and would therefore seek to undermine that - the Soviet goal would be to disrupt U.S. hegemony in the region. ${ }^{96}$ Indeed, by late 1947 , as a result of the Rio Pact, or Inter-American Treaty of Reciprocal Assistance, hemisphere solidarity was achieved, effectively

\footnotetext{
${ }^{93}$ Office or Reports and Estimates, "ORE 16, Soviet Objectives in Latin America," Central Intelligence Group, (4 March 1947), 1, https://www.cia.gov/library/readingroom/document/0000256978 (accessed 21 July 2017).

${ }_{94}$ ORE 16, Soviet Objectives in Latin America, 2-3.

${ }_{95}^{9}$ ORE 16, Soviet Objectives in Latin America, 3.

${ }^{96}$ ORE 16, Soviet Objectives in Latin America, 2-3. The Rio Pact effectively ended major Soviet intentions in Latin America, as assessed by CIG. Smaller scale subversive activity was still a concern of intelligence and national security planners, however.
} 
undercutting any Soviet aims in Latin America. However, ORE assessed that Soviet intelligence, military, and diplomatic officers would continue to support local communist parties, trade/labor unions, and propaganda efforts, in addition to maintaining intelligence collection efforts against the U.S. and in order to maintain small scale subversive activity following the Rio agreement. ${ }^{97}$ An addendum to the report outlines the minority opinion, in which only State Department analysts offer dissent for this assessment, suggesting CIG analysts were being too guarded. ${ }^{98}$ State Department analysts criticized the CIG, who attributed communist growth to propaganda and ignorance, rather than economic distress, social maladjustment, and frustrated nationalism. ${ }^{99}$

After the transformation of CIG into CIA in late 1947, ORE produced an updated version of their analysis on Soviet intentions in Latin America. CIA ORE 16/1, drafted in November 1947, nearly echoed the assessment produced by CIG only months before. ORE 16/1 assessed that the Soviet government anticipated an inevitable conflict with the capitalist world. CIA's ORE still acknowledged the Soviet goal was to undermine U.S. hegemony in the region, but ORE now suggested that the Soviets would also try to undermine U.S. access to Latin American resources. ${ }^{100}$ In contrast to previous analysis by the CIG, CIA assessed that except for a noted few countries, most Latin American nations would not be able to prevent communist attempts at disrupting hemispheric trade or Soviet manipulations of the local economy. ${ }^{101}$ Unlike ORE 16's

\footnotetext{
${ }^{97}$ ORE 16, Soviet Objectives in Latin America, 2-4.

${ }^{98}$ Dissenting views are included in larger estimates that are written collaboratively by the various elements of the intelligence community. By including these alternative views, analysts display adherence to tradecraft standards by ensuring that all views are considered and evaluated and the judgement with the most weight/ acceptability are the primary view. Dissenting views are usually annexed as minority judgements.

${ }^{99}$ ORE 16, Soviet Objectives in Latin America, 6.

${ }^{100}$ Office or Reports and Estimates, "ORE 16/1, Soviet Objectives in Latin America," Central Intelligence Agency, (6 Oct 1947), 1, https://www.cia.gov/library/readingroom/document/0000256612 (accessed 21 July 2017

${ }^{101}$ ORE 16/1, Soviet Objectives in Latin America, 6. Many of CIA's analysts had also worked for CIG. The change in their assessments over time likely arose from new sources, new tradecraft standards, or new collection and reporting priorities. A certain paternalism and ethnocentrism existed in many reports in the late 1940s and early 1950s as evidenced in the lack of confidence analysts placed on certain Latin American
} 
single dissenting addendum, an addendum with dissenting views from the Office of Naval Intelligence (ONI) and the State Department was included in ORE 16/1. ONI recognized the many reasons communism would have difficulty taking hold in Latin America, namely the Catholic religion, existing conservative military branches, U.S. influence, the Rio Pact, and Latin America's economic dependence on the U.S. ONI did not feel that CIA had valid reasons or enough sources to reach the conclusion it did regarding Soviet intentions in Latin America. ${ }^{102}$

Moving ahead to the 1950s, after the establishment of ONE, estimative intelligence products drafted by ONE and crucial to the NSC and administration's decision to move forward with covert action included: SR 46 (27 July 1950), CIA/RE 34-49 (14 November 1950), NIE 3 (15 November 1950), NIE 62 (11 March 1952), and NIE 84 (19 May 1953). These sources will be reviewed here, including how they informed talking points at NSC meetings, aiding in the decision making process.

Published 27 July 1950, SR 46, Guatemala, provided important background information on Guatemala's political situation, economic situation, presence of saboteurs and subversive elements, foreign affairs, military situation, and probable future developments. A moderate length production, the document spanned a significant portion of Guatemalan history, from the colonial period through the Cold War, and focused primarily on the Arevalo administration, the changes seen therein, and what could be expected for the final two years of his term. CIA estimative analysts (ONE was not yet created) who drafted this SR suggested that:

"Guatemala has some strategic importance to the United States because of... its privilege, as an independent nation, of taking action incompatible with US security interests; its production of tropical hardwoods and abaca, and its potentialities as an oil

countries to think for themselves, act independently, and protect themselves from external influences like communism.

${ }^{102}$ ORE 16/1, Soviet Objectives in Latin America, 9. 
producing area; its potential influence of neighboring Central American countries; and its location within the US Defense sphere." 103

Guatemala's potential influence of neighboring Central American countries became a critical facet of future analysis and NSC discussions. ${ }^{104}$ These analysts, like the State Department officials mentioned above, also linked the emerging nationalism in Guatemala to socialism. "Guatemala has also sought to bring about the establishment of sympathetic governments in neighboring countries by giving aid to international revolutionary movements." 105 Juan Jose Arévalo, elected as President from 1945-1951, earned favor with the laboring class, alienating many of the landed elite and wealthy, upper class members of Guatemalan society. CIA linked Arévalo to communists by highlighting his willingness to employ, subsidize, and encourage communists. ${ }^{106}$ Most significant in SR 46, however, is the assessment that despite a robust and favored communist influence in the country, "it is believed that Guatemala's basic alignment with the U.S. would result, in the event of a U.S.- USSR war, in the suppression of communist activities." 107 While U.S. national security concern was understandably engaged in the Korean peninsula, CIA analysts astutely looked to the future, predicting that:

"Although the positive contribution which Guatemala could make toward US security is slight, its geographic position makes it of conceivable value to an enemy of the US. It

\footnotetext{
${ }^{103}$ Central Intelligence Agency, "SR 46: Guatemala," (27 July 1950), 3, https://www.cia.gov/library/readingroom/document/cia-rdp78-01617a001700030001-9 (accessed 21 July 2017).

${ }^{104}$ Record of minutes from $132^{\text {nd }}$ meeting of the NSC, 18 February 1953, from Ann Whitman Papers, 19531961: NSC Series. Box No.: 4, Eisenhower Library, Abilene, Kansas. The $132^{\text {nd }}$ NSC meeting held discussion on Guatemala's influence on its neighbors, and officials at the meeting were concerned that Guatemala's neighbors were concern for the growth of communism and were considering potential military action to curb its growth. The NSC's discussion on Guatemala's neighbors considering military action suggests that a fear existed within those countries regarding communist subterfuge emanating from Guatemala.

${ }^{105}$ Cullather, Secret History, 15 and Foreign Relations of the United States, 1951, The United Nations; The Western Hemisphere, Volume II, 1419, eds. Ralph Goodwin, N. Stephen Kane, and Harriet Schwar (Washington: Government Printing Office, 1979), Document 800, https://history.state.gov/historicaldocuments/frus1951v02/d800 (accessed 20 July 2017) and Central Intelligence Agency, "SR 46: Guatemala," 4.

${ }^{106}$ Central Intelligence Agency, "SR 46: Guatemala," 3.

${ }^{107}$ Central Intelligence Agency, "SR 46: Guatemala," 3.
} 
could be used for propaganda dissemination and espionage, or as a base for attacks against the Panama Canal, the Venezuelan oil fields, Caribbean shipping, or other potential Western Hemisphere targets." 108

This assessment echoes previously discussed ORE analytic products, both from the CIG and early CIA. What SR 46 offers is a glimpse of what is to come in Guatemala... the paternalistic assessment that "a friendly and stable government in Guatemala favors US security, and because Guatemala is incapable of defending itself against a strong enemy, denial of its facilities and resources to an enemy power is primarily a US responsibility." 109 The fear of communist influence in Guatemala had not changed from 1947 to 1950, nor would it in the coming years.

President Truman, an avid consumer of CIA intelligence products, was not eager to pursue covert options in Guatemala in $1950 .{ }^{110}$ Yet as Arévalo's leftist-nationalist administration transitioned to Árbenz' pro-communist regime and PBFORTUNE took shape, the organizational disparity between the State Department and CIA manifested itself. As noted, Secretary Acheson clung to FDR's “Good Neighbor” policy, while CIA planners like CIA Deputy Director for Plans (DD/P) Allen Dulles (soon to be DCI) and Joseph Caldwell King, chief of CIA's Western Hemisphere Division, sought to overthrow the democratically elected leader. ${ }^{111}$ It would not be until the election of Eisenhower and the appointment of the Dulles brothers, John Foster and Allen, to the State Department and CIA, respectively, that a unity of effort emerged within the administration, albeit still rife with organizational agendas. ${ }^{112}$

\footnotetext{
${ }^{108}$ Central Intelligence Agency, "SR 46: Guatemala," 4.

${ }^{109}$ Central Intelligence Agency, "SR 46: Guatemala," 4.

${ }^{110}$ CIA Directorate of Intelligence Historical Series, "A History of the Central Intelligence Bulletin 19511967," Center for the Study of Intelligence (1967), 1

${ }^{111}$ Cullather, Secret History, 27-33.

112 Garry Clifford, "Bureaucratic Politics," 91. This allows for the use of bureaucratic politics and national security framework to guide the analysis of this history. The major complication arises from latent agendas from the Truman administration. Allen Dulles clearly wanted to remove pro-communist leadership in Guatemala from the early 1950s. John Foster had replaced Secretary Acheson, and was not as keen to maintain Good Neighbor relations, despite the Rio Pact, because he saw communist influence in Latin America as a
} 
In late 1950 DCI Smith was directed to produce an estimate of Soviet Capabilities and Intentions, which analysts did, publishing on 15 November 1950 a National Intelligence Estimate entitled NIE 3 Soviet Capabilities and Intentions. This estimate made a critical misjudgment, one of which led to the second surprise of 1950 (the first being the North Korean invasion of South Korea in June): the failure to predict Chinese infiltration and involvement in the Korean War, which began in late November. NIE 3 failed to predict that China would act unilaterally, without guidance from Moscow, and while not overtly stating it, the estimate credits the Kremlin with monolithic control of global communism. Soviet objectives included the "domination of Korea," the "[consolidation]...over the European and Asian satellites (including Communist China)" and "to establish Soviet domination over Europe and Asia." ${ }^{113}$ NIE 3 analysts posited that China had no reasons of its own to attack into North Korea and were dependent on "Soviet material aid" to succeed and that "the North Korean attack appears to mark a significant step forward in the Kremlin's strategy...despite actual US reactions." ${ }^{114}$ However, and understandably, NIE 3 had no mention of Latin America or Soviet intentions in the region. ${ }^{115}$ This intelligence estimate corroborates Ambassador Peurifoy's comment that the Kremlin managed and directed global

form of foreign interference (which had been the hallmark of the Monroe Doctrine), and assessed that U.S. intervention in Latin America against communism was not intervention at all, but a maintenance of traditional policy. Together the Dulles brothers worked to advise Eisenhower and shape his decision making process by justifying their respective organizations agendas, which happened to work in tandem, unlike under the previous administration. Disunion of organizational values and prerogatives existed prior to Eisenhower, specifically before the Solarium talks. That is not to say things were completely unified after mid-1953. However, in regard to Guatemala, the CIA and State Department worked towards a common goal with a shared value.

${ }^{113}$ Central Intelligence Agency, Office of Reports \& Estimates, "NIE-3: Soviet Capabilities and Intentions," National Intelligence Estimate (15 Nov 1950), pp.1, 3, 23, https://www.cia.gov/library/readingroom/document/cia-rdp86b00269r000300040009-5 (accessed 21 July 2017).

${ }^{114}$ Office of Reports \& Estimates, "NIE-3," pp. $2,7$.

${ }^{115}$ This is not to say that when discussing Soviet Strategic Intentions and Campaigns in the Event of Global War (as seen on page 10 of NIE 3) that the CIA does not recognize Soviet intentions to conduct subversive activities and sabotage against Anglo-American interests in all parts of the world. 
communism. ${ }^{116}$ These analytic errors, accompanied by a poorly developed collection networks in Korea, sparked the modifications within the CIA discussed earlier in this chapter.

The day prior to the NIE publication, 14 November 1950, CIA did produce an assessment regarding Soviet capabilities and intentions in Latin America, CIA RE 34-49, which explains the omission of Latin America in NIE 3. CIA RE 34-39's bottom-line-up-front judgement supported many of the same assessments previously proposed regarding Soviet intentions in Latin America, but introduced some new judgements, namely that the Soviets would attempt the following:

"(1) winning support of Soviet positions by exploiting certain patterns in Latin American life that facilitate the Communist approach and by taking advantage of specific incidents for propaganda purposes (2) reducing the extent of Western Hemisphere solidarity by exploiting historical antagonisms, opposed intensely nationalistic sentiments, and conflicting national interests; (3) causing dissention between political factions in some countries (particularly Bolivia, Ecuador, Chile, Cuba, and Guatemala) to the point of impairing political stability and of shifting the balance of power; (4) taking direct military action by harassing sea lines of communication between the US and Latin American through submarine action and by landing sabotage agents and small commando parties; and (5) and most important, reducing Latin American economic support of the US in several important fields." 117

Comparatively, and in contrast to SR 46 produced just months earlier, this assessment suggests that potential Soviet actions in Latin America may increase and do so in a nefarious and damaging manner. These types of up front judgements were discussed often at NSC meetings during the sunset years of Truman's administration as well as in the early days of Eisenhower's.

As CIA analysts predicted in SR 46, the final years of Arévalo's administration went by with heightened tension and uncertainty, but with no major incident. In March 1951, Jacobo Árbenz-Guzman became Guatemala's next democratically elected president. Supported by the Partido Accion Revolucionaria and Partido Renovacion Nacional and other groups during the

\footnotetext{
${ }^{116}$ Cullather, Secret History, 26, and House Select Committee on Communist Aggression, Communist Aggression in Latin America, 83rd Cong., 2d sess., 1954, p. 125.

${ }^{117}$ Central Intelligence Agency, "CIA RE 34-49, Soviet Capabilities and Intentions in Latin America," (14 November 1950), 1, https://www.cia.gov/library/readingroom/document/0000258824 (accessed 21 July 2017).
} 
1950 elections, Árbenz won on platforms that supported revolutionary principles and "land reform beneficial to the Indians; support and development of labor movements; extension and development of social security; nationalization of land that is standing idle; and the 'liberation' of Guatemala from foreign economic domination." ${ }^{118}$ CIA analysts assessed Árbenz' policy agenda in mid-1950. By 1952, and CIA's next significant Guatemalan assessment (NIE 62 Present Political Situation in Guatemala and Possible Developments During 1952), many of their predictions had come true, elevating concern at the Agency and in the administration.

CIA assessed an "out of proportion" influence from communist factions in Guatemala on the Árbenz administration and stated that such influence would "probably continue to grow during 1952." ${ }^{119}$ Again, analysts noted that opposition to communism in Guatemala had potential, but was without a centralizing motivation and had no organized effort. ${ }^{120}$ The CIA also assessed that any outcome in Guatemala would "in large measure" depending on the resolution of conflict between the United Fruit Company (UFCo) and the Árbenz government. Written before Decree 900, NIE 62 perceptively linked past, present, and future conflict between Guatemala and UFCo to the 1944 Revolution and nationalism. ${ }^{121}$ The fact that a U.S. company was a key facet of foreign policy has long driven historians to assess that the fruit company was the motivation behind intervention in Guatemala. NIE 62 suggests that it was important, but not the pivotal focus of forthcoming U.S. policy. Additionally, UFCo was the subject of heated debate between Eisenhower's staff. At an NSC meeting in June 1953, discussion on anti-trust

\footnotetext{
${ }^{118}$ Central Intelligence Agency, "SR 46: Guatemala," 9-10.

${ }^{119}$ Foreign Relations of the United States, 1952-1954, Guatemala, eds. Susan Holly and David Patterson (Washington: Government Printing Office, 2003), 6.

${ }^{120}$ Foreign Relations of the United States, 1952-1954, Guatemala, 7.

${ }^{121}$ The uprising in June 1944 ousted President Jorge Ubico from office. Democratic elections were held in December 1944, with Juan Jose Arevalo assuming the Presidency on March 15, 1945. The revolution is seen as a nationalist effort to establish Guatemalan identity, so a political party who can identify itself with the revolution would win the support of a larger percent of the population.
} 
proceedings levied by the Justice Department against UFCo resulted in the decision to postpone any legal action until the political situation in Guatemala had been resolved. ${ }^{122}$ Secretary Dulles and the DCI both advised against anti-trust proceedings at this meeting. The importance of analytic assessments and evidence of who read them can be seen in NIE 62, which stated "if the Company should submit to Guatemalan demands the political position of the Árbenz Administration would be greatly strengthened." ${ }^{123}$ CIA analysts judged that an economic deterioration in Guatemala would give communists the room they needed to assert themselves further. $^{124}$

Using communist-controlled international labor organizations, Guatemalan communist party members were assessed to be "in open communication with international communism." 125 Furthermore, Árbenz had promoted or appointed communists to several government positions, including the National Electoral Board, Institute of Social Security, labor courts, the propaganda office, and the official press and radio. ${ }^{126}$ While communists only held four of the 61 congressional seats, the fact that such important and visible offices elsewhere now contained communists resonated with CIA analysts. Cullather notes, as well, that more than these government positions, the close friendship between Árbenz and Jose Manuel Fortuny, leader of the Partido Guatemalteco del Trabajo (PGT), was cause for concern. The final major CIA product drafted about Guatemala before Decree 900 and before the election of Dwight Eisenhower, the closing paragraph of NIE 62 is ominous and foreshadowing:

"In the longer view, continued Communist influence and action in Guatemala will gradually reduce the capabilities of the potentially powerful anti-Communist forces to

\footnotetext{
${ }^{122}$ Record of minutes from $148^{\text {th }}$ meeting of the NSC, 4 June 1953, from Ann Whitman Papers, 1953-1961: NSC Series. Box No.: 4, Eisenhower Library, Abilene, Kansas.

${ }_{123}^{123}$ NIE 62, Foreign Relations of the United States, 1952-1954, Guatemala, 7.

${ }^{124}$ Foreign Relations of the United States, 1952-1954, Guatemala, 12.

${ }^{125}$ Foreign Relations of the United States, 1952-1954, Guatemala, 9.

${ }^{126}$ Foreign Relations of the United States, 1952-1954, Guatemala, 10.
} 
produce a change. The Communists will also attempt to subvert or neutralize the Army in order to reduce its capability to prevent them from eventually taking full control of the Government." 127

Eisenhower entered office in 1953 with a number of challenges, not the least of which was the situation in Guatemala. CIA reported to NSC members, via a new NIE, that the "current situation in Guatemala is adverse to US interests" and that communists in Guatemala likely sought to divorce Guatemala from its relationship with the U.S. in order to "convert its Government into an effective... instrument of Communism." ${ }^{128}$ After the failed attack at Salama in March, any opposition to Árbenz and the communists was unlikely. ${ }^{129}$ Throughout 1953 , the implementation of the Agrarian Reform Law of 1952 was thought to be the principal objective of the Árbenz administration, leaving landholders and UFCo as victims, mobilizing rural workers in support of the administration, and affording communists the opportunity to extend their influence to the peasantry. ${ }^{130}$ CIA analysts emphasized, in closing, the "serious consideration to the possibility of effecting a political change in Guatemala through clandestine support of revolutionary activities" from the anti-communist governments of El Salvador, Honduras, and Nicaragua. ${ }^{131}$ Military action from one or all of these nations would be ineffectual against Guatemala's army. As the summer of 1953 wore on, the NSC met to discuss options. The situation was quickly deteriorating, and a policy paper drafted for an August NSC meeting noted that "In Guatemala Communism has achieved its strongest position in Latin America, and is now well advanced on a program which threatens important American commercial enterprises in that

\footnotetext{
${ }^{127}$ Foreign Relations of the United States, 1952-1954, Guatemala, 13.

${ }^{128}$ Central Intelligence Agency, Office of National Estimates, "NIE 84, Probable Developments in Guatemala," National Intelligence Estimates, (8 May 1953), 1-2, https://www.cia.gov/library/readingroom/document/0000914889 (accessed 21 July 2017).

${ }^{129}$ Office of National Estimates, "NIE 84," 3, and Cullather, Secret History, 34.

${ }^{130}$ Office of National Estimates, "NIE 84," 19.

${ }^{131}$ Office of National Estimates, "NIE 84," 21.
} 
country and may affect the stability of neighboring governments." 132 This comment from the August NSC meeting again demonstrates the importance of NIEs at Council meetings. The policy paper drafted as a result of the meeting called for collaboration between Guatemala and the United States to resolve political and economic conditions and reduce the effectiveness of communists in the country and offered input on how to achieve these aims. "Withholding of further loans, grants and other favors from the Guatemalan Government," the increased isolation of Guatemala from its Central American neighbors, arms embargos, anti-communist covert information programs, and aiding previously identified anti-communist elements in Guatemala, all demonstrated the desire by those in Eisenhower's administration to act. ${ }^{133}$

Thoroughly discussed here, estimative intelligence analysis provided policymakers with the extensive, evolving, and corroborative narrative necessary to a firm understanding of Guatemala's geopolitical situations. Armed with this baseline, Eisenhower's top planners, John Foster Dulles and Allen Dulles, for example, could proceed with plans to overthrow Árbenz based on their situational understanding, which was made possible by CIA analytic products. Moving forward, these top-level planners also needed real-time, newsflash style updating to keep abreast of a dynamic and changing situation. To provide such news, CIA's Office of Current Intelligence offered the Current Intelligence Bulletin six times per week to the President's office and his staff.

\footnotetext{
${ }^{132}$ Foreign Relations of the United States, 1952-1954, The American Republics, Volume IV, eds. N. Stephen Kane, William Sanford, Jr., and William Slany (Washington: Government Printing Office, 1983), Document 424, 1075. Draft Policy Paper Prepared in the Bureau of Inter-American Affairs, NSC Guatemala, August 19, 1953, https://history.state.gov/historicaldocuments/frus1952-54v04/d424 (accessed 20 July 2017).

${ }^{133}$ Foreign Relations of the United States, 1952-1954, The American Republics, 1077.
} 


\section{OFFICE OF CURRENT INTELLIGENCE}

The Central Intelligence Bulletin (CIB), a precursor to the modern Presidents Daily Brief, offered "simple and straightforward [information] to the President of the United States and highlevel U.S. Government policy-makers each day of the most noteworthy intelligence and to provide an evaluation of it." ${ }^{134}$ From its inception, however, the CIB struggled to "command the attention" of those key decision-makers that it intended. ${ }^{135}$ Indeed, President Eisenhower himself rarely, if at all, read the CIB. As CIA historians note, "'informing the President' does not necessarily involve his own reading of the publication." ${ }^{136}$ The Presidents top advisors read the bulletin and informed him of the most important issues during National Security Council meetings, but could also be selective with what information was passed. Eisenhower's trust in staff work and those who he surrounded himself will be discussed in chapter three.

The CIB afforded policymakers at the highest level bottom-line-up-front (BLUF) intelligence, tailored with the understanding that the readership would have limited time for consumption. The CIB usually consisted of a title page, distribution list and table of contents, and body of analysis. A typical CIB would break down news by region or topic. An article would have a descriptive title and two to three paragraphs-one or two explaining the current event, and another one or two giving analyst commentary about the event. This newspaper like publication gave Eisenhower's staff and the National Security Council the most up-to-date information, usually ahead of private media, or at least with more authority, nuance, and reliable source material. Eisenhower himself, ever one who preferred discussion with advisors and informative conversation over unilateral decision-making, insisted that those on his staff like

\footnotetext{
${ }^{134}$ CIA Directorate of Intelligence Historical Series, “A History of the Central Intelligence Bulletin 19511967," Center for the Study of Intelligence (1967), 1.

${ }^{135}$ Directorate of Intelligence Historical Series, “A History of the Central Intelligence Bulletin 1951-1967,” 1.

${ }^{136}$ Directorate of Intelligence Historical Series, “A History of the Central Intelligence Bulletin 1951-1967," 1.
} 
John Foster and Allen Dulles digest the CIB and use the information therein to augment their discussions at various high-level meetings.

After Guatemala's Congress passed Árbenz' agrarian reform law in 1952, CIA OCI analysts drafted a CIB that informed Eisenhower's staff that there were "scattered riots in rural areas, attempts have been made to dynamite hydroelectric plants in several cities, and there have reportedly been numerous arrests. A revolution may be inspired by large landowners and other anti-communists." ${ }^{137}$ In an aggressive move, Árbenz ordered all firearm licenses revoked and began patrol flights over the entire country. However, despite the caution, OCI analysts still commented that "there is no evidence that the widespread anti-government and anti-Communist activity is now sufficiently coordinated for a successful revolution." 138

In the late summer of 1953, after the NSC had met and discussed the best way forward in Guatemala, Eisenhower authorized the CIA to coordinate and develop a plan to remove Árbenz. ${ }^{139}$ As plans unfolded, OCI analysts reported that "Guatemalan president Árbenz made clear to Ambassador Peurifoy on 16 December that he intends to continue to collaborate with the communists. He displayed his deep feeling against the United Fruit Company, and said that it would be better for Guatemala to be dominated by the communists than by the company." 140

\footnotetext{
${ }^{137}$ Office of Current Intelligence, "Agrarian reform law may cause revolution in Guatemala," Central Intelligence Bulletin, (22 June 1952), https://www.cia.gov/library/readingroom/document/ciardp79t00975a000700350001-5 (accessed 20 July 2017).

${ }^{138}$ Office of Current Intelligence, "Agrarian reform law may cause revolution in Guatemala," Central Intelligence Bulletin, (22 June 1952), https://www.cia.gov/library/readingroom/document/ciardp79t00975a000700350001-5 (accessed 20 July 2017).

${ }^{139}$ Cullather, Secret History, 38. Referencing NSC policy paper from 19 August, 1953, which is discussed above. Source: Central Intelligence Agency, Job 79-01025A, Box 76, Folder 2. Secret; Eyes Only. Sent through Wisner. Another memo from Kinto to DCI via Wisner on 17 August 1953 also details the options available to the CIA operations in Guatemala, while supporting RUFUS, code for Armas and his rebels. ${ }^{140}$ Office of Current Intelligence, "Guatemalan president plans continued collaboration with communists," Central Intelligence Bulletin, (22 Dec 1953), https://www.cia.gov/library/readingroom/document/ciardp79t00975a001400070001-8 (accessed 20 July 2017).
} 
"Guatemala's top communist leaders, Gutierrez and Fortuny...were "honest" and served Guatemalan, not Soviet, interests. [Árbenz] said that they had gone to Moscow "merely to study Marxism, not necessarily to get instructions." 141 Árbenz' dedication to communism seemed to justify Ike's decision earlier that summer.

Part of the plan to discredit and eventually overthrow Árbenz involved overt diplomatic efforts from John Foster Dulles' State Department. ${ }^{142}$ The Eisenhower administration called an OAS meeting to take place at Caracas, Venezuela in March 1954, in order to push an agreement between OAS members to support anti-communism in the hemisphere. This was, to those involved, a clear attack on Guatemala. On 18 March, Secretary Dulles addressed the NSC regarding the Caracas Conference. A month prior, Árbenz accused the U.S. of “intervention” visà-vis support to plotters against the Árbenz regime, which OCI analysts suspected would harm the U.S. position at Caracas, specifically as it related to the Rio Pact and non-intervention. ${ }^{143}$ At the NSC meeting, however, Dulles felt OAS members could be swayed if he outlined U.S. policy towards Guatemala by drawing on traditional and contemporary understanding of U.S. foreign policy. ${ }^{144}$ Dulles used the traditional understanding of the Monroe Doctrine as a basis for continued U.S. policy, but extended this to the "outlawing of foreign ideologies in the American

\footnotetext{
${ }^{141}$ Office of Current Intelligence, "Guatemalan president plans continued collaboration with communists," Central Intelligence Bulletin, (22 Dec 1953). CIA analysts tracked travel plans for Gutierrez and Fortuny, as they traveled to Moscow, and posited that the trip was to receive instruction from the Soviets for future subversive activities.

${ }^{142}$ Cullather, Secret History, 40.

${ }^{143}$ Office of Current Intelligence, "Guatemala expected to raise charge of US intervention at Caracas conference," Current Intelligence Bulletin, (2 Feb 1954), https://www.cia.gov/library/readingroom/document/cia-rdp79t00975a001400380001-4 (accessed 20 July 2017).

${ }^{144}$ Secretary Dulles consumed OCI products, but did not always have to agree with the assessment when briefing at NSC meetings or when preparing comments for other meetings. Here he used OCI warning to prepare his argument for Caracas.
} 
Republics" as well as foreign (non-hemispheric) intervention. ${ }^{145}$ Dulles argued that by articulating foreign ideological incursion in such a manner, he would be able to gain support to "effectively meet communist subversion in the American Republics," further commenting that "communist subversion and subsequent control of any of the American Republics was tantamount to external aggression against such a Republic." ${ }^{146}$ Securing the acceptance of anticommunism had not been easy. Árbenz, in his March 1, 1954 State of the Nation speech challenged Dulles, asking international audiences "for clarification of what was meant by intervention, [stating that] under international law neither a doctrine nor an organization but only a state can be guilty of intervention." OCI analysts commented "the speech suggests that Guatemala may raise questions of international law at Caracas to confuse further the scheduled discussion of Communist intervention." They noted that "lengthy debate among the Latin Americana, who pride themselves on their proficiency in international law, on the propriety of ascribing any intervention to an ideology or movement, and could result in the Caracas resolution on the subject being as vaguely worded as the one passed in 1948 at Bogota and in 1951 at Washington." ${ }^{147}$ Dulles did not balk at the difficulty, shutting down fears that the U.S. would use anti-communism as a "pretext for intervention into the internal affairs of the others republics of the hemisphere." 148

Discussed at the May 13 meeting of the NSC, fears that Guatemala communists would begin to influence unrest in neighboring Central American countries became reality when

\footnotetext{
${ }^{145}$ Record of minutes from $189^{\text {th }}$ meeting of the NSC, 18 March 1954, from Ann Whitman Papers, 1953-1961: NSC Series. Box No.: 5, Eisenhower Library, Abilene, Kansas.

${ }^{146}$ Record of minutes from $189^{\text {th }}$ meeting of the NSC, 18 March 1954, from Ann Whitman Papers, 1953-1961: NSC Series. Box No.: 5, Eisenhower Library, Abilene, Kansas.

${ }^{147}$ Office of Current Intelligence, "Arbenz speech may presage new Guatemalan tactics at Caracas," Central Intelligence Bulletin,(4 March 1954), https://www.cia.gov/library/readingroom/document/ciardp79t00975a001400620002-6 (accessed 20 July 2017).

${ }^{148}$ Record of minutes from $189^{\text {th }}$ meeting of the NSC, 18 March 1954, from Ann Whitman Papers, 1953-1961: NSC Series. Box No.: 5, Eisenhower Library, Abilene, Kansas.
} 
Honduran UFCo employees launched a strike. The situation was seen as "very serious" with OCI analysts later in the month suggesting Árbenz was nervous about the potential of an OAS meeting directly in response to issues within Guatemala. OCI suggested in late May that Árbenz would continue to try to appease local Latin American leaders by seeking nonaggression pacts, specifically with Honduras. ${ }^{149}$

At Guatemala's Caribbean port of Puerto Barrios on May 15, 1954, the Swedish shipping vessel Alfhem docked, offloading tons of arms and ammunition purchased in secret in Czechoslovakia. ${ }^{150}$ Because of the restrictions placed on Guatemala by the U.S. as a result of the previous summer's NSC policies, Guatemala now had to look elsewhere for weapons and training. On 22 May, OCI commented "Guatemala has not asked for extension of the US army and air mission agreements which lapsed over a year ago. Both missions are still in Guatemala and enjoy cordial relations with Guatemalan officers." ${ }^{151}$ Additionally, regarding the shipment of weapons, they stated, "The equal division of the new equipment, the type of which is still unknown, between the two regiments in the capital appears designed to prevent either from gaining preponderant strength. It indicates awareness of the decisive role key commanders could play in any attempt to overthrow the government." ${ }^{152}$ On 27 May the NSC met again to discuss, among numerous other things, what to do should Guatemalan aggression continue. Specifically, Executive Secretary Lay, Secretary Dulles, and the President discussed options for enforcing arms embargos, Secretary Dulles noting "various countries would not accord formal recognition

\footnotetext{
${ }^{149}$ Office of Current Intelligence, "Comment on Guatemalan offer of nonaggression pact with Honduras," Central Intelligence Bulletin, (29 May, 1954), https://www.cia.gov/library/readingroom/document/ciardp79t00975a001600040001-9 (accessed 20 July 2017).

${ }^{150}$ Cullather, Secret History, 77.

${ }^{151}$ Office of Current Intelligence, "Guatemala may request 'European technicians' for advise on new arms," Central Intelligence Bulletin, (22 May 1954), https://www.cia.gov/library/readingroom/document/ciardp79t00975a001500610001-7 (accessed 20 July 2017).

${ }^{152}$ Office of Current Intelligence, "Guatemala may request 'European technicians' for advise on new arms," Central Intelligence Bulletin.
} 
of our right to detain and search their vessels on the high seas, but they would be willing to look the other way while we did this." ${ }^{153}$ To further fuel angst regarding whether Guatemala was supporting subversive communist activity in neighboring countries, Secretary Dulles also commented that some of the arms shipped on the Alfhem were likely in use at strikes in Honduras, suggesting that Guatemalan communists provided weapons to Honduran labor unions. ${ }^{154}$ The Attorney General briefly commented that stopping vessels on the high seas to search them was typically outside the realm of acceptable international law, but in cases of selfdefense would be acceptable. However, he warned the Council, that it should be prepared for a "division among the international lawyers on this [issue]." ${ }^{155}$ Eisenhower, therefore authorized the U.S. Navy to halt any vessels suspected of shipping arms to Guatemala.

The NSC met on 17 June, the day before Armas crossed the line of departure on his invasion from Honduras, and discussed UFCo and the Attorney General's dissatisfaction with the continued stalling of anti-trust proceedings. The AG wished to proceed with anti-trust proceedings against the fruit company while Eisenhower suggested an additional year be given to the company to allow it to investigate the possibility of divorcing its inconsistent practices. ${ }^{156}$ DCI Dulles commented that with nationalist movements in Latin America, UFCo would likely be forced to relinquish its monopoly on rail and electric services in Guatemala, but for the Justice Department to force the issue at the present moment would give Árbenz an advantage. Dulles also noted that within a month, the situation with UFCo in Guatemala could be more favorably

\footnotetext{
${ }^{153}$ Record of minutes from $199^{\text {th }}$ meeting of the NSC, 27 May 1954, from Ann Whitman Papers, 1953-1961: NSC Series. Box No.: 5, Eisenhower Library, Abilene, Kansas.

${ }^{154}$ Record of minutes from $199^{\text {th }}$ meeting of the NSC, 27 May 1954, from Ann Whitman Papers, 1953-1961: NSC Series. Box No.: 5, Eisenhower Library, Abilene, Kansas.

${ }^{155}$ Record of minutes from $199^{\text {th }}$ meeting of the NSC, 27 May 1954, from Ann Whitman Papers, 1953-1961: NSC Series. Box No.: 5, Eisenhower Library, Abilene, Kansas.

${ }^{156}$ Record of minutes from $202^{\text {nd }}$ meeting of the NSC, 17 June 1954, from Ann Whitman Papers, 1953-1961: NSC Series. Box No.: 5, Eisenhower Library, Abilene, Kansas.
} 
"clarified" at another meeting, indicating Dulles' confidence in the quick overthrow of Árbenz. ${ }^{157}$ The AG agreed to continue stalling anti-trust proceedings.

From the beginning of June until the 18th, OCI continued to draft CIBs that highlighted preparations for another OAS meeting, this one called to specifically address Guatemala. On the sixth, analysts commented on Mexico's willingness to meet, and that this would likely influence other uncommitted governments to consider such a meeting. Mexican President Adolfo Ruiz Cortines was in favor of Eisenhower's policy of an arms embargo to stem militant communist activities in Guatemala, and was open for additional discussion. ${ }^{158}$ OCI reported on 10 June that a required majority of two thirds of OAS members had agreed to meet to discuss Guatemala. Three days later it reported that Argentinian President Juan Peron, a centrist populist, reaffirmed his support of an OAS meeting, but asked to broaden the discussion to communist intervention everywhere in the hemisphere, not just Guatemala. Peron also stated he had "hard facts" about communist plans in the hemisphere and would bring them to any OAS meeting. ${ }^{159}$ OCI was not aware, however, that the mechanism was already in motion to overthrow Árbenz. DCI Dulles and his operations director Frank Wisner kept strict secrecy on PBSUCCESS, "neither seeking nor receiving aid from other directorates" within the Agency, to include the DI, ONE, or OCI. ${ }^{160}$

${ }^{157}$ Record of minutes from $202^{\text {nd }}$ meeting of the NSC, 17 June 1954, from Ann Whitman Papers, 1953-1961: NSC Series. Box No.: 5, Eisenhower Library, Abilene, Kansas.

${ }^{158}$ Office of Current Intelligence, "Mexico to support OAS meeting on Guatemala," Central Intelligence Bulletin, (6 June 1954), https://www.cia.gov/library/readingroom/document/cia-rdp79t00975a001600110001-1 (accessed 20 July 2017). Additionally, a CIB on 8 June noted that CIA analysts believed communists already had possession of some weapons, but not enough to defend the administration against a rebel army.

${ }^{159}$ Discussion of the plan for an OAS meeting on Guatemala. Office of Current Intelligence, "Peron reaffirms support for calling OAS on Guatemala," Central Intelligence Bulletin, (13 June 1954) https://www.cia.gov/library/readingroom/document/cia-rdp79t00975a001600170001-5 and Office of Current Intelligence, "Required majority agrees to OAS meeting on Guatemala," Central Intelligence Bulletin, (10 June 1954), https://www.cia.gov/library/readingroom/document/cia-rdp79t00975a001600140001-8 (accessed 20 July 2017)

${ }^{160}$ Cullather, Secret History, 44. 
As such, once the operation launched, OCI's CIBs created a play-by-play of events for toppolicy makers, keeping them abreast of events as they unfolded.

At the NSC meeting of June 24th, DCI Dulles updated Eisenhower's staff on the unfolding operation in Guatemala. Only a week old, PBSUCCESS seemed on tenuous ground. On 20 June, OCI analysts stated the outcome was still very much in doubt, and predominantly dependent on the position of the Guatemalan armed forces, who gave no real indication of their intentions. ${ }^{161}$ OCI reported that information coming out of Guatemala, both from pro-Árbenz radio transmissions and Armas' "Radio Liberation" transmission, were being exaggerated. In desperation, however, a government broadcast did call for labor unions to submit membership lists as a possible roster for potential civilian defenders of the capital. ${ }^{162}$ DCI Dulles, drawing on information gleaned from OCI and other Agency reports, stated on the 24th that the situation was largely unchanging, but that Guatemala's armed forces were demonstrating significant indecisiveness. ${ }^{163}$

A last minute comment was added to the already completed June 27 th CIB just before distribution to Eisenhower's staff. In the body of reporting, it was noted that the Guatemalan Army was poised to act against Árbenz, but was waiting for word from an unidentified leader. Further, it stated that Árbenz was in poor shape internationally after the UN refused to acknowledge appeals from Árbenz without first receiving a report from the OAS. The last minute addition ended the Eisenhower administration's most complex covert action by

\footnotetext{
${ }^{161}$ Office of Current Intelligence, "Comment on the Guatemalan situation as of 20 June," Central Intelligence Bulletin, (20 June 1954), https://www.cia.gov/library/readingroom/document/cia-rdp79t00975a0016002300018 (accessed 20 July 2017).

${ }^{162}$ Office of Current Intelligence, "The situation in Guatemala," Central Intelligence Bulletin, (22 June, 1954), https://www.cia.gov/library/readingroom/document/cia-rdp79t00975a001600240001-7 (accessed 20 July 2017).

${ }^{163}$ Record of minutes from $204^{\text {nd }}$ meeting of the NSC, 24 June 1954, from Ann Whitman Papers, 1953-1961: NSC Series. Box No.: 5, Eisenhower Library, Abilene, Kansas.
} 
headlining: "Guatemalan Army takes over Government from Árbenz." Chief of Army Forces Colonel Carlos Enrique Diaz had taken over the government. ${ }^{164}$ Árbenz made a short radio address before stepping down, condemning UFCo and "U.S. ruling circles" for the conflict but promised that Diaz would carry on the popular will and all pro-democratic organizations should support him. ${ }^{165}$ OCI reported two days later that the new military government had outlawed the communist party in Guatemala, but rebel forces led by Colonel Armas had yet to reconcile or meet with the new Diaz regime. ${ }^{166}$ Further, Ambassador Peurifoy, who continued for days to ensure Armas came to power, made no effort to recognize Diaz as the new leader. Diaz' associate, Colonel Elfego Monzon assumed control from Diaz by the 30th, and worked with Peurifoy, the Salvadoran government, and Armas to agree on a peace settlement. Ultimately, within weeks of launching the coup and with support from Eisenhower's State Department and the CIA, Castillo Armas succeeded in ousting Árbenz and condemning communism in Guatemala. $^{167}$

Thursday, July 1, the 205th meeting of the NSC took place at the White House, and despite Guatemalan political stability remaining a concern for Eisenhower, DCI Dulles and his brother John Foster Dulles brought the overthrow operation to a conclusion for Eisenhower. Describing the situation without Árbenz as "somewhat better" DCI Dulles echoed the information presented in OCI's June 30th CIB. No resolution to the leadership issue had yet

\footnotetext{
${ }^{164}$ Office of Current Intelligence, "Demoralization reported in Guatemalan government and army," Central Intelligence Bulletin, (27 June 1954), https://www.cia.gov/library/readingroom/document/ciardp79t00975a001600290001-2 (accessed 20 July 2017).

165 Office of Current Intelligence, "Demoralization reported in Guatemalan government and army," Central Intelligence Bulletin, (27 June 1954).

${ }^{166}$ Office of Current Intelligence, "New military government of Guatemala reportedly outlaws Communist Party," Central Intelligence Bulletin, (29 June 1954), https://www.cia.gov/library/readingroom/document/ciardp79t00975a001600300001-0 (accessed 20 July 2017).

${ }^{167}$ Office of Current Intelligence, "Comment on the Guatemalan negotiations," Central Intelligence Bulletin, (30 June 1954), https://www.cia.gov/library/readingroom/document/cia-rdp79t00975a001600310001-9 (accessed 20 July 2017).
} 
happened but would likely resolve itself in the coming days or weeks. ${ }^{168}$ Eisenhower commented that the desertion of Guatemalan communists after the fall of Árbenz suggested that perhaps the communist problem in Guatemala was not as significant as he believed, but rather communism was just a tool used by power-hungry politicians and activists. Secretary Dulles and the DCI quickly took issue with Eisenhower's assessment, reassuring him that the move to overthrow Árbenz was entirely justified since "the communist group in Guatemala included a number of Moscow-trained communists." ${ }^{169}$ Communist propaganda concerned Eisenhower, who then led a discussion on how best to bring up the fact that Moscow was, in fact, managing Guatemala's communists to U.S. media outlets. The Dulles brothers, informed from CIA DI/ ONE/ ORR/ OCI production, and their own personal understanding of Soviet intentions, believed Moscow was controlling Árbenz, and as such advised the president, resulting in an intervention that destroyed Guatemala's experiment with democracy.

The NSC had no guarantee that Colonel Armas would win. CIA analysts did suggest that the Guatemalan armed forces would be the most crucial factor to a victory over Árbenz, but it was not possible to gauge success based on this variable. Eisenhower's policy makers took a gamble. Covert action may succeed, or it could fail, but the hand of the U.S. needed to remain hidden. Using diplomacy via OAS meetings in early 1954 offered legitimacy to overt anticommunist efforts by the U.S. Coupled with CIAs covert paramilitary, economic, and psychological operations, success would be more likely. If Árbenz could be overthrown using this combination of overt and covert action, all the better for Eisenhower's staff. If he remained in power, then the gamble would not be entirely in vain: after Caracas a hemispheric front,

\footnotetext{
${ }^{168}$ Record of minutes from $205^{\text {th }}$ meeting of the NSC, 1 July 1954, from Ann Whitman Papers, 1953-1961: NSC Series. Box No.: 5, Eisenhower Library, Abilene, Kansas.

${ }^{169}$ Record of minutes from $205^{\text {th }}$ meeting of the NSC, 1 July 1954, from Ann Whitman Papers, 1953-1961: NSC Series. Box No.: 5, Eisenhower Library, Abilene, Kansas.
} 
unified against communism, would gradually wear away at Árbenz' credibility and further damage communist activities in the hemisphere. Secretary Dulles and his brother, united in their organization's efforts to rid Guatemala of communism, had a more or less win-win situation and were successfully able to bring Eisenhower on board with their plan to quietly remove Árbenz.

This study of current and estimative intelligence, seeing what Eisenhower and his staff were presented with by CIA analysts, aids in understanding how decisions were made at NSC meetings. Information in ONE and OCI reports clearly translated to a number of policy meetings early on in Eisenhower's presidency. Policy makers often feel more secure in their decision once they have that "secret" information from analysts that they cannot get from the Washington Post or Time magazine. The Dulles brothers felt secure in recommending action against Árbenz, not just because analysts said action would be needed, but also because what analysts suggested synced with non-secret sources, and because it could alleviate some of the anxiety felt by all during the red scare. Analysis of secret facts only helped solidify their judgements. However, analysis is not simply reading a crystal ball and getting the story indisputably correct. Analysts can, have been, and will continue to be wrong. The important part of ONE and OCI analysts' job was to ensure adherence to doctrinal tradecraft, analytic rigor, objectivity, thoughtfulness, and articulation of confidence and probability levels, thereby reducing uncertainty for policy makers and giving them a decision advantage. To the Dulles brothers, Eisenhower, and the National Security Council, Árbenz was directly linked to Moscow via his close relationship with top Guatemalan communists. As the situation deteriorated, his removal seemed the most logical option. 


\section{CHAPTER 3: IKE'S DECISION}

\section{EISENHOWER'S SOURCES}

Returning home a victor from World War II, Dwight Eisenhower symbolized patriotism and greatness. His "famous smile, broad and beaming, wide-open and boyish in its delight" made it easy for Americans to like him. ${ }^{170}$ Eisenhower projected the image of a thoughtful grandfather who had the confidence of the American people, but often fumbled once engaged within the political spectrum. Historian Evan Thomas, author of Ike's Bluff: President Eisenhower's Secret Battle to Save the World, notes that Eisenhower had a strong "disdain for politics and politicians." 171 Very few knew what political affiliations Ike possessed. President Truman assumed Eisenhower was a Democrat, offering to campaign for him if he should run for President. But it was not until Republican New York Herald Tribune owner, John Hay Whitney organized a rally for Eisenhower at Madison Square Garden in early 1952 that Ike made clear his political slant. ${ }^{172}$ Once elected, Eisenhower's grandfatherly image continued to garner him support from Americans; he enjoyed some of the highest popularity ratings of any president. Americans trusted Ike's "air of restrained, manly confidence," his judgement, and his military acumen-which they assumed would translate to safety. ${ }^{173}$ Yet many scholars went on to criticize Eisenhower as being unsuited for the responsibility of the presidency, criticizing him as the "pliable puppet of his aides." 174 Political Scientist Fred Greenstein argues that Eisenhower appeared to be the "epitome of a nonleader," basing his judgement on Eisenhower's often disjointed press conferences and speeches, "replete... with scrambled syntax" and often

\footnotetext{
${ }^{170}$ Evan Thomas, Ike's Bluff: President Eisenhower's Secret Battle to Save the World (New York: Back Bay Books, 2013), 7.

${ }^{171}$ Thomas, Ike's Bluff, 9.

172 Thomas, Ike's Bluff, 9.

173 Thomas, Ike's Bluff, 16.

${ }^{174}$ Fred Greenstein, The Hidden-Hand Presidency (New York: Basic Books, 1984), viii.
} 
confusing. ${ }^{175}$ However, careful study of Eisenhower by Greenstein and others have shown that Ike was very much the "alert, politically astute [president] who engaged in the traditional kinds of persuasion and bargaining which are the standard activities of other presidents but which were believed to have been abjured by the amiable Ike." ${ }^{176}$ As president, Eisenhower faced immense challenges both domestically and abroad. To remain informed and up to date, specifically on Guatemala, Ike relied not only on his professional foreign policy advisors, but also on media accounts and public opinion, his brother Milton, and pressure from U.S. businesses threatened by foreign governments. In terms of the crisis in Guatemala, all of these factors played out a dynamic calculus in Ike's mind, ultimately resulting in his decision to authorize PBSUCCESS. Understanding why Ike authorized the Arbenz overthrow demands an awareness of his advisors, as well as the roll external sources played in his decision-making. Greenstein states that "he...not Secretary of State John Foster Dulles, was the engine force of the...presidency." ${ }^{177}$ Eisenhower was able to use the image of amiable grandfather to assuage the American people, all the while using his analytical, thoughtful, and strategic acumen to quietly work for the defense of the Western world against communism. ${ }^{178}$ This chapter seeks to show the various sources of information Eisenhower used to conclude action was needed in Guatemala. By understanding that complex arithmetic, a more nuanced understanding of the 1954 overthrow will emerge.

\section{US FOREIGN POLICY AND THE DULLES BROTHERS}

President Eisenhower's brother, Milton, President of Pennsylvania State College from 1950 to 1956 was one of Ike's top advisors, especially regarding Latin American issues. Milton

\footnotetext{
${ }^{175}$ Greenstein, The Hidden-Hand Presidency, viii.

${ }^{176}$ Greenstein, The Hidden-Hand Presidency, $i x$.

${ }^{177}$ Greenstein, The Hidden-Hand Presidency, viii.

${ }^{178}$ Greenstein, The Hidden-Hand Presidency, $x$-xi.
} 
travelled to Latin America numerous times during Ike's presidency to elucidate the geopolitical situations of various Central and South American countries, once in 1953 and once in 1958. As such, Milton became an ad hoc diplomat and foreign service representative for the president. Secretary Dulles and Ike often discussed the reports that Milton provided after his trips, and after Milton's first trip, Ike requested Treasury, DoD, and State conduct a thorough study of Milton's report with conclusions being briefed to the president once complete. ${ }^{179}$ President Eisenhower found Milton's report striking and fascinating, but wanted additional information and review from other advisors before drawing any conclusions himself. ${ }^{180}$ There were no shortages of Latin Americanists for Ike to draw upon for detailed information on events south of the Rio Grande.

Eisenhower also relied on his intelligence professionals for information that he could not gain by other means. His top spy, Allen Dulles, had a well cultivated anti-communist slant. In Dulles' autobiography, The Craft of Intelligence, he notes that early in the Cold War Iranian leader Mossadegh and Guatemalan president Arbenz "[came] to power through the usual processes of government and not by any communist coup as in Czechoslovakia. Neither man at the time disclosed the intention of creating a communist state." Following World War II, both Iran and Guatemala experienced a period of anti-colonial nationalism that resulted in revolutionary experiments in democracy and government. Dulles' statement attempts to connect nationalist policy with communism. CIA assessed that communists were bending nationalist policy to their will, yet little was offered in the way of hard facts to support this judgement. Dulles said "when [the communist] purpose became clear, support from outside was given to

\footnotetext{
${ }^{179}$ Dulles, John Forster: Papers, 1951-59, Subject Series, Box No.: 5, Eisenhower Library, Abilene, Kansas. Review of Milton Eisenhower report to President Eisenhower after being reviewed by Dept. of State, et. al. ${ }^{180}$ Dulles, John Forster: Papers, 1951-59, Subject Series, Box No.: 5, Eisenhower Library, Abilene, Kansas. Memorandum for the Secretary of State, January 12, 1954, from DDE instructing DoS to conduct a multidepartmental review of Milton's report.
} 
loyal anti-communist elements in the respective counties-in the one case, to the Shah's supporters' in the other, to a group of Guatemalan patriots."

Dulles also states that:

"Where communism has achieved control of the governmental apparatus of a country... should we as a country shy away from the responsibility of continuing efforts to right the situation and to restore freedom of choice to the people? Are we worried that the charge be made that we, too, like, Khrushchev, had our own policy of "wars of liberation"? ${ }^{181}$

Dulles was clearly concerned with strategic Cold War power projection, and made countering Soviet intentions the focus of the Agency. Dulles' association with UFCo (as a former legal counselor and shareholder) played a minor role in his personal calculus, but many of his statements indicate a sense of benevolent ideological responsibility for the preservation of democracy and free-trade against communist subversion. Dulles assumed that Arbenz, vis-à-vis communism, would undermine the democratic process in Guatemala and her neighbors creating a beachhead for the USSR in Latin America. Historian Nick Cullather contends, however, that "twice [Arbenz] had risked his life and career for democracy," and despite his land reform policies, Arbenz demonstrated little in the way of disrupting the democratic practice in Guatemala. $^{182}$

Bureaucratic politics and organizational rivalry hindered the Truman administration from finding common ground on which to fight back against Guatemala's perceived communist threat. Secretary of State Dean Acheson of the State Department was unable to reconcile policy differences with CIA's Allen Dulles and Chief of Western Hemisphere Divisions J.C. King. Because of this, early plans to overthrow Arbenz were tabled. The unifying efforts undertaken by President Eisenhower in the summer of 1953, in a way, helped solve this reconciliation problem.

${ }^{181}$ Allen W. Dulles, The Craft of Intelligence (Guilford, Connecticut: The Lyons Press, 2006), 232.

${ }^{182}$ Cullather, Secret History, 20. 
The Solarium talks, meant to formulate a single, concise policy for dealing with the Soviet Union, resulted in a common policy that all of Ike's staffers and agencies could rally behind. Eisenhower felt that Secretary Dulles thought the Soviet Union was much more "rash" than he did and knew his military would continue to lobby for more troops and better weapons. With greater military might, the urge to use it might arise. The Solarium talks were Eisenhower's way of "getting ahead of this dynamic" to ensure that everyone was on the same page regarding the way forward against global communism. ${ }^{183}$ Bureaucratic politics would undoubtedly continue as a factor in the application of policy, as State, DoD, CIA, Treasury, and many other departments sought ways to further their respective agendas in regard to Guatemala. But the results of the Solarium talks, NSC 162/2, as well as the close relationship of CIA and State with the Dulles brothers at the helm, was the sharing of common values and objectives in dealing with communism.

On June 30, 1954 Secretary Dulles dialed his brother Allen to discuss the conclusion of events and overthrow of Arbenz. At the next day's NSC meeting they would discuss with the president the best message to give the press regarding the situation. Although the CIB from earlier that day suggested no resolution for the power struggle had yet been reached, the situation was looking slightly better, especially with communism outlawed. During the telephone conversation, the brothers discussed that between 200-400 communists had taken refuge in embassies around Guatemala City. ${ }^{184}$ Two days prior, the brothers spoke over the phone about their shared happiness over the outlawing of communism in Guatemala and the selection of the

\footnotetext{
${ }^{183}$ Thomas, Ike's Bluff, 105-109.

${ }^{184}$ Record of Telephone Call to Mr. Allen Dulles, June 30, 1954, 8:44a.m, from ${ }^{184}$ Dulles, John Forster: Papers, 1951-59, Subject Series Dulles, John Foster: Papers. Telephone Conversation Series. Box No.: 1, A6728. Eisenhower Library, Abilene, Kansas.
} 
"right fellow" to replace Arbenz. ${ }^{185}$ In mid-June, as the outcome of PBSUCCESS remained unclear and efforts were still being pushed to call an OAS meeting to discuss Guatemala, Secretary Dulles again dialed his brother who was lunching with Assistant Secretary of State for Inter-American Affairs, Henry Holland, and discussed the evidence of association between the Soviet Union and Guatemala. The three men felt that this critical point, judged likely by OCI and ONE analysts, was critical enough to discredit Arbenz at the planned OAS meeting. ${ }^{186}$ The close connection and unity of effort between the brothers to ouster Arbenz demonstrates the policy solidarity shared between the CIA and State Department. Secretary Dulles, at times, had to be reassured that their efforts would succeed, especially as diplomatic tensions were elevated after Armas invaded Guatemala. The combined action of overt and covert methods would work, DCI Dulles assured his brother on June 24th. ${ }^{187}$ With the Dulles brothers driving the ship, it makes clear the power and influence they enjoyed behind advising Eisenhower. These telephone conversations between the Dulles brothers, as well as the issues discussed at the 205th meeting of the NSC, show the influence they had on Eisenhower, as well as the trust he had in their efforts. Solarium and NSC 162/2 put State and CIA on the same sheet of music. John Foster and Allen's personal connection ensured a common goal and the policy solidarity that Eisenhower wanted. This made it easier for Eisenhower, who trusted his advisors to have the answers he wanted and to cultivate his policy decisions - to include authorizing covert action in Guatemala—based on the advice given by his staff.

\footnotetext{
${ }^{185}$ Record of Telephone Call to Mr Allen Dulles, June 28, 1954, 5:06 p.m., from Dulles, John Foster: Papers. Telephone Conversation Series. Box No.: 1, A67-28. Eisenhower Library, Abilene, Kansas.

${ }^{186}$ Record of Telephone Call to Mr Allen Dulles, Saturday June 26, 1954, 3:24 pm, from Dulles, John Foster: Papers. Telephone Conversation Series. Box No.: 1, A67-28. Eisenhower Library, Abilene, Kansas.

${ }^{187}$ Record of Telephone Call to Mr Allen Dulles, Thursday June 24, 1954, 2:01p.m, from Dulles, John Foster: Papers. Telephone Conversation Series. Box No.: 1, A67-28. Eisenhower Library, Abilene, Kansas.
} 


\section{US MEDIA AND PUBLIC OPINION}

The 1950s brought nearly unparalleled growth to the United States, economically and in terms of morale. World War II had helped kick the depression and the post war boom aided in creating a consumer society. Many Americans purchased televisions and Eisenhower became the first president to utilize television broadcasting to communicate directly with the public. The visual transmission of Ike's smile hid the dire truth of the Cold War from many, as Americans contented themselves that Eisenhower was at work keeping them safe.

Printed media — newspapers, journals, and magazines — continued to bring domestic and international news into American homes. Eisenhower was an avid consumer of print media, as were most Americans. Time magazine's weekly publication was a staple around the nation. As the situation in Guatemala developed and United Fruit Company stifled under the regimes of Arevalo and Arbenz, the company hired Edward Bernays, regarded as a trailblazer in American public relations. ${ }^{188}$ Bernays had, over the years, cultivated a rich relationship with many of the major news and magazine companies in the U.S. He was able to convince many news agencies to send correspondents to Guatemala during the early 1950s, who reported on several "political disturbances" and that the "Communist movement had colonized Guatemala." "189 Hired to influence U.S. public opinion in favor of UFCo, Time and other publications, having been “convinced" by Bernays of the injustices suffered by UFCo once Arbenz' land reform policy began expropriating land in 1953, published accounts largely in favor of United Fruit and called land reform proof of the "communistic" leanings of Arbenz. ${ }^{190}$ Scholars Stephan Schlesinger and Stephen Kinzer noted that Time magazine "typified the U.S. media response" to many Guatemalan issues, often publishing anti-Arbenz articles and calling Guatemala the "Western

\footnotetext{
${ }^{188}$ Kinzer and Schlesinger, Bitter Fruit, 80.

${ }^{189}$ Kinzer and Schlesinger, Bitter Fruit, 84.

${ }^{190}$ Kinzer and Schlesinger, Bitter Fruit, 88.
} 
Hemisphere's Red problem child." ${ }^{191}$ Bernays experienced success as a result of his efforts to sway the media. Ambassador Peurifoy, in 1954, discussed U.S. public opinion with a Time correspondent, suggesting that the U.S. public would be in favor of intervention in Guatemala simply to "prevent Guatemala from falling into the lap of international Communism." ${ }^{192}$ Top decision makers in Guatemala City and in Washington felt that U.S. public opinion was in favor of action against a communist regime in Latin America. More critical is the fact that public opinion, and what the media projected, was also of vast significance to the resident of a prominent home on Pennsylvania Avenue.

Scholar David Barrett's Sterilizing a "Red Infection": Congress, the CIA, and Guatemala, 1954, offers a nuanced interpretation of the 1954 coup, suggesting that landowning elites in Guatemala were partly responsible for forming a coup climate by "[persuading] US journalists and members of Congress.... That their government was veering further and further leftward toward Communism." ${ }^{193}$ Barrett argued that Congressional interest and involvement, vis-à-vis Guatemala and U.S. media, and notes that although Congress was not completely read in on the CIA's operations, "fragmentary" evidence suggests that Congress was aware of and comfortable with stopping "ongoing Soviet aggression" in Guatemala. ${ }^{194}$ Barrett also quotes Senator Alexander Wiley of Wisconsin, who chaired the Foreign Relations Committee, citing "There is no Communism but the Communism which takes orders from the despots of the Kremlin in Moscow," suggesting that not only was the CIA and State Department concerned

\footnotetext{
${ }^{191}$ Kinzer and Schlesinger, Bitter Fruit, 129.

${ }^{192}$ Immerman, CIA in Guatemala, 138.

${ }^{193}$ David M Barret, "Sterilizing a 'Red Infection,' Congress, the CIA, and Guatemala, 1954," Center for the Study of Intelligence, (2007), https://www.cia.gov/library/center-for-the-study-of-intelligence/kentcsi/vol44no5/html/v44i5a03p.htm (accessed 20 July 2017).

${ }^{194}$ Barret, "Sterilizing a 'Red Infection,"” Barret argues a congressional role in intelligence policy. This, he notes, its counter to the narrative that congressional oversight of intelligence activities was lacking until the Church Committee investigations in the 1970s.
} 
with Moscow's influence in Guatemala, but members of Congress as well. ${ }^{195}$ Not only was the printed media influencing public opinion, it was driving decision makers in Washington.

As tension grew in Guatemala, New York Times, Time, and Reuter's correspondentssome sent at the request of Bernays-were ejected from Guatemala in 1953 and 1954. Key Guatemalan government broadcasting and media outlets, run by Arbenz appointed communists, were dissatisfied with the rhetoric these correspondents were transmitting. ${ }^{196}$ Sydney Gruson of Time was "expelled...for writing a piece on November 6, 1953, depicting the President [Arbenz] as a captive of Communists in his government." ${ }^{197}$ Time magazine called the delivery of arms aboard the Alfhem "the Red bloc's first public display of big-brotherly trust and confidence in Guatemala." ${ }^{198}$ Printed media was just another modality of information Eisenhower and his staff used to decide on the proper course of action and justify their cause. On June 14, 1954, Time printed an article that corroborated what OCI analysts had been reporting, stating the "Guatemalan Reds [were] worrying [their] neighbors," publishing photos of Soviet weapons seized in Honduras and Nicaragua as well as UFCo strikers in Honduras. ${ }^{199}$ Furthermore, once the coup began, Time published accounts praising Armas for leading the fight against communism, attempting to dispel propaganda that the U.S. was secretly involved in any way. ${ }^{200}$ Eisenhower's staffers and political advisors were receiving classified accounts of this and also reading about it in the open press. To any with access to the information available to Eisenhower via his advisors, his calculus seemed justified and clear.

\footnotetext{
${ }^{195}$ Barret, "Sterilizing a 'Red Infection."”

${ }^{196}$ Barret, "Sterilizing a 'Red Infection,"” and Frederick Marks, III., "The CIA and Castillo Armas in Guatemala, 1954: New Clues to an Old Puzzle," Diplomatic History, Vol 14, No.1, 79.

${ }_{197}$ Marks, "The CIA and Castillo Armas," 79.

${ }^{198}$ Immerman, The CIA in Guatemala, 158.

199 "Guatemalan Reds Worry Neighbors: Honduras and Nicaragua fuss over arms," Time, 14 June 1954, 39-40.

200 "A Guatemalan Revolution That Everyone Expected," Time, 28 June 1954, 12-13 and "Reds' Priority: Pin War on US," Time, 5 July 1954, 8-13.
} 


\section{UNITED FRUIT COMPANY}

Historian Frederick Marks stated "no serious student of the period can deny that there were close connections between UFCo and members of the Eisenhower administration." 201 Indeed, Eisenhower's personal secretary, Ann Whitman, was the wife of UFCo's director of public relations (who hired Bernays). Marks notes that:

"Assistant Secretary Cabot had a brother who had been a UFCo president in 1948; and Dulles's law firm, Sullivan and Cromwell, had ties to UFCo. In addition, Henry Cabot Lodge was a stockholder; Undersecretary Smith was seeking UFCo executive posting during the planning stage of the revolution; and Robert Hill, American ambassador to Costa Rica during the revolution, had worked for Grace Shipping Lines with important interests in Guatemala. UFCo donated an estimated $\$ 64,000$ in cash to the cause of Castillo Armas." 202

Kinzer and Schlesinger's account, Bitter Fruit, delves holistically into the extensive relationships that existed between the Eisenhower administration and United Fruit. Interestingly enough, however, they cite a Time correspondent who posited "If the United Fruit Company had not existed, there would have been no U.S. pressure or intervention. The U.S. wouldn't have cared. With no threats to U.S. property, there would have been no problem." ${ }^{203}$ There are those, however, who would argue that UFCo was merely a facet of a much more complex issue. Even PGT leader Fortuny, in an interview with Piero Gleijeses stated that "they would have overthrown us even if we had grown no bananas." 204

Piero Gleijeses argues that, after reviewing the historical record, "it becomes clearer and clearer that while the U.S. embassy's concern with communism under Arevalo owed much to UFCo's smoke and mirrors, its concern with communism under Arbenz owed little to the

\footnotetext{
${ }^{201}$ Marks, "The CIA and Castillo Armas," 84

${ }^{202}$ Marks, "The CIA and Castillo Armas," 84-85.

${ }^{203}$ Kinzer and Schlesinger, Bitter Fruit, 203 and Gleijeses, Shattered Hope, 361 also highlights and expands upon these connections. Ike's pro-business administration was "studded with friends of United Fruit."

${ }^{204}$ Gleijeses, Shattered Hope, 366.
} 
company." ${ }^{205}$ Gleijeses, who in the late 1980 s and early 1990s, reviewed what little analytic intelligence documentation as had been declassified at that point, noted that a shift in analytic rigor and quality occurred within the State Department's Office of Intelligence and Research as well as in the CIA's Directorate of Intelligence from the late 1940s to the early 1950s. He notes that early dispatches from the embassy in Guatemala City lacked accuracy and bore "no relationship to the reality of Guatemala" and that amidst the world of McCarthyism and the red scare, early products and dispatches "[inhabited] a deranged world of nightmares." ${ }^{206}$ Without adequate reporting from intelligence collectors and diplomats in Guatemala City, or within the analytic centers of Washington, the media and public relation campaigns of men like Bernays easily swayed the minds of decision makers. Gleijeses suggests, however, that UFCo lost some of its ability to shape the narrative after analysts exercised more rigor following the reorganization efforts within CIA early in the 1950s. He notes traditional "arrogance and ethnocentrisms" are still noticeable in many State Department dispatches and some intelligence products, but by the mid-1950s intelligence professionals had a much better grasp on the situation in Guatemala and were able to dominate the narrative, shifting it from one controlled by UFCo's propagandists, to one dominated by analysts and senior policymakers. Kinzer and Schlesinger, along with Gleijeses, argue that Guatemala, unlike other Latin American counties whose communist parties were shrinking and lacked a direct connection to the president, was a singular bastion of communism and, as such, became an obvious concern for the U.S. ${ }^{207}$ Arbenz' association with, and support of, communism and the agrarian reform law, was an "intolerable

\footnotetext{
$\overline{205}$ Gleijeses, Shattered Hope, 362.

${ }^{206}$ Gleijeses, Shattered Hope, 363.

${ }^{207}$ Gleijeses, Shattered Hope, 362-366.
} 
challenge to America's sense of self-respect." ${ }^{208}$ In 1953 and 1954, according to Gleijeses, United Fruit was a factor, but not the reason Eisenhower chose to intervene in Guatemala.

\section{EISENHOWER'S LEARNING STYLE, PSYCHOLOGY, AND DECISION MAKING}

Author of Groupthink or Deadlock: When Do Leaders Learn from Their Advisors, Paul Kowert calls information the "lifeblood of decision making." 209 This study has looked at the sources of Eisenhower's information, both open-source information-media, public opinion, and the business lobby - as well as the secret, analyzed information called intelligence. It has sought to elucidate what was available to Eisenhower and although it remains impossible to know exactly how Ike performed the requisite calculus that lead to his decision to authorize PBSUCCESS, a look at his learning style, psychology, and management style can reveal more about how he may have arrived at his decision.

Eisenhower was often thought of as being "politically innocent" or as being the puppet of his advisors. ${ }^{210}$ There is a certain "protection" against blame for poor decisions if a leader remains distant from the politics behind those decisions, something often referred to as "plausible deniability" in contemporary vernacular. ${ }^{211}$ Indeed, most media sources in the $1950 \mathrm{~s}$ found it impossible to cast blame on Eisenhower for his role in the overthrows of Mossadegh and Arbenz. ${ }^{212}$ Historian Richard Immerman suggested that John Foster Dulles, "relentless in his

\footnotetext{
${ }^{208}$ Gleijeses, Shattered Hope, 366.

${ }^{209}$ Paul Kowert, Groupthink or Deadlock, When Do Leaders Learn from Their Advisors? (Albany: State University of New York, 2002), 2.

${ }^{210}$ Fred Greenstein, The Hidden-Hand Presidency: Eisenhower as Leader (Baltimore: The Johns Hopkins University Press, 1994), $x$.

${ }^{211}$ Both Greenstein, The Hidden-Hand Presidency, $x$, and Kowert, Groupthink or Deadlock, 2, discuss deniability as a way leaders might pad themselves from political injury for bad decisions. Both authors, however, state then later argue that although Ike gave off the impression that he was political distance or even incapable, he was very much involved and maintained an air of distance from the real policy making in order to use his genial public image to ease the tenuous atmosphere of the cold war.

${ }^{212}$ Greenstein, The Hidden-Hand Presidency, 62.
} 
opposition to communism around the world," was the true "architect" of foreign policy in Ike's administration, and as such the easy choice when assigning blame for botched policy. ${ }^{213}$

Looking at Eisenhower's decision-making style, Kowert argues that it is not easy to "distill a clear picture" but that two major theories have emerged to aid in understanding his learning style and decision-making process. ${ }^{214}$ First, as noted, many in the 1950 s thought that Ike was ineffectual, indecisive, and uninformed. Second was a revisionist interpretation of his presidential activity. It "portrayed Eisenhower as a dignified, intelligent, and shrewd politician" and suggests that Ike was very much active in the decision making process, even taking ownership of final decisions. ${ }^{215}$ Eisenhower, remembered not just for his presidency but for his commanding role in World War II's European theater, demonstrates his active role in decisionmaking and planning, as well as owning final decisions, very clearly in a note he penned in the case of a failed Normandy invasion. Written June 5 1944, General Eisenhower said if any blame were to be given for a failed attack, it should be his alone. ${ }^{216}$ Additionally, Kowert notes Eisenhower was also a deliberate and thoughtful planner, mentioning that the president himself said that "unless circumstances and responsibility demanded an instant judgement, I learned to reserve mine until the last proper moment." ${ }^{217}$ This also shows Eisenhower's affinity for conversation and debate before decisions were made. Indeed, the "New Look" policy was drafted as a result of the Solarium talks at which Eisenhower allowed for the presentation, discussion, and debate of three different courses of action. Eisenhower allowed each presenter to articulate the benefits of their respective policies before "astonishing" his advisors and the

\footnotetext{
${ }^{213}$ Kowert, Groupthink or Deadlock, 32.

${ }^{214}$ Kowert, Groupthink or Deadlock, 34.

${ }^{215}$ Kowert, Groupthink or Deadlock, 34.

${ }^{216}$ National Archives Catalog, "In Case of Failure Message Drafted by General Dwight Eisenhower in Case the D-Day Invasion Failed, https://catalog.archives.gov/id/186470 (accessed 21 July 2017).

${ }^{217}$ Kowert, Groupthink or Deadlock, 34.
} 
presenters by succinctly and accurately recapping all three suggestions and making a final decision on the best policy himself. ${ }^{218}$ Eisenhower's staff secretary, Andrew Goodpaster, stated that the president did not learn "anything that he hadn't already thought through before" but that Eisenhower wanted to ensure the due diligence of the decision making process by discussing the policy topics, as well as forming consensus within his advisory circle. ${ }^{219}$

Understanding the psychology of Eisenhower also aids in gaining a rudimentary grasp on his decision making process. Kowert notes that many biographers believe Eisenhower's childhood upbringing, family life, and military career gave him "every reason to become a selfassured, confident adult." ${ }^{220}$ Biographer Stephen Ambrose noted that Ike's parents "consistently encourage him to look to himself in both success and failure. ${ }^{221}$ Kowert argues that this mentality influenced Eisenhower throughout his life and that psychologists call one's "personal belief in their ability to shape events and determine outcomes an 'internal locus of control.", 222 Most important, "Eisenhower entrusted the most important decisions to only himself." 223

Kowert forms the basis of his study of learning styles on a simple understanding of introversion versus extroversion, and links learning styles to the decision making process and management styles of leaders. He argues that, as would be expected, a "greater incentive to attend to advice and evidence from their surroundings" is needed from introverts, while extroverts are naturally open to things external to themselves, including advice. ${ }^{224}$ Next Kowert suggests that the locus of control plays a major role in learning and making decisions, stating that "internals" feel that they can control outcomes through hard work, whereas "externals" believe

\footnotetext{
218 Thomas, Ike's Bluff, 108-109.

219 Thomas, Ike's Bluff, 109.

${ }^{220}$ Kowert, Groupthink or Deadlock, 37.

${ }^{221}$ Kowert, Groupthink or Deadlock, 37.

${ }^{222}$ Kowert, Groupthink or Deadlock, 37.

${ }^{223}$ Kowert, Groupthink or Deadlock, 38.

${ }^{224}$ Kowert, Groupthink or Deadlock, 15.
} 
fate or those more powerful than themselves control situations and outcomes. ${ }^{225}$ Relying on the studies of Julian Rotter, Kowert suggests that "internals are more likely than externals to gather information on their environments" in order to gain understanding. ${ }^{226}$ The use of introversion/extroversion and internal/external personalities, Kowert notes, can add confusion, because internals are actually interested in their surroundings because they feel they can change outcomes, whereas externals are not as interested because they do not feel as in control as they would like. All of these postulations combined, and because of the confusion in the above terms, Kowert adopts an easier label for the two types of learning styles he discusses: "open individuals who desire a great deal of diverse information and advice, and closed individuals who rely primarily on their own instincts and on a much smaller quantity and variety of information to make decisions.", 227

Kowert maintains that leaders with an open style learn best when offered advice from a number of advisors with a diverse set of opinions and information (an open advisory structure), while closed style leaders will perform well with small groups of advisors who share similar values (a closed advisory structure). ${ }^{228}$ With all these distinctions presented, Kowert explains that if open learners/leaders rely on closed advisory structures instead, the problem of groupthink can emerge, while if closed learners/leaders rely on an open advisory structure, deadlock could occur. Understanding Eisenhower, his learning style, and decision-making philosophy, requires a grasp on this information. Kowert suggests Ike was on open learner, who used open advisory groups for certain issues, and closed advisory groups for others. The National Security Council meetings, because of the nature of the subjects discussed, were often very closed groups, full of

\footnotetext{
${ }^{225}$ Kowert, Groupthink or Deadlock, 16.

${ }^{226}$ Kowert, Groupthink or Deadlock, 17.

${ }^{227}$ Kowert, Groupthink or Deadlock, 17.

${ }^{228}$ Kowert, Groupthink or Deadlock 22-23.
} 
thinkers and advisors with similar desires to stamp out communism, and in the case of Guatemala, as analytic reporting continued to back what Eisenhower's advisors believed, groupthink developed that almost certainly lead to Eisenhower's decision to authorize PBSUCCESS. ONE and OCI assessments discussed in chapter two made their way to the leaders at NSC meetings and corroborated the judgments of those in attendance, contributing to the groupthink behind the policy decision on Guatemala.

Fred Greenstein suggests that Eisenhower, with his "open eagerness" and enthusiasm to learn, encouraged his advisors to feel more a part of a "collective enterprise" than "defenders of [their respective] departmental positions." ${ }^{229}$ The Solarium talks give a striking example of Eisenhower's desire to develop a consolidated opinion on policy. Meetings and debates were not just forums for policy planning either... Greenstein suggests that Eisenhower, by having all of his department heads in one location, could easily "coordinate their activities." ${ }^{230}$ Eisenhower also knew that, unlike in his past, the job of president would be one that he could not simply prepare for through study and personal development. Ike commented to a colleague that his traditional method of preparing for a new job with thoughtfulness and study would have to be "discarded" because of the "the infinite variety of problems presented, and the rapidity with which they are placed in front of the responsible individual for action." ${ }^{231}$ Eisenhower admitted that he needed his advisors, and relied heavily on them when making decisions because "they help to meet the deficiencies of a faulty memory, a deteriorating disposition, and any tendency towards the pessimistic" and that advisors helped him form a common sense decision that he would not otherwise be able to make alone. ${ }^{232}$ These decisions, although formed through the

\footnotetext{
${ }^{229}$ Greenstein, The Hidden-Hand Presidency, 115-116.

${ }^{230}$ Greenstein, The Hidden-Hand Presidency, 116.

${ }^{231}$ Kowert, Groupthink or Deadlock, 41.

${ }^{232}$ Kowert, Groupthink or Deadlock, 41.
} 
contributions of many, including the variety of sources discussed in this study, remain Eisenhower's alone, shouldered by the same leader who was willing and able to take on the full measure of responsibility for any potential failures. 


\section{CONCLUSION}

Intelligence analysts use a variety of information sources when drafting their assessments. Human reporting, imagery, collected signals, and measurable signatures are some of the types of sources available to analysts trying to see the bigger picture. Compartmentalizing the methods used in obtaining the information protects most of these sources. The more diverse the set of sources are, and the more they corroborate each other, the easier it can be for an analyst to form a solid conclusion about an event or prediction. Analysts are also trained to detect intentional deception and to identify when a piece of information may not be what it seems. In Guatemala some collection efforts suggested that Árbenz was not communist and that the threat was not as dire as others suggested. In October 1952, for example, a report from the field went back to headquarters for analysts to use in their reporting stating that "Rather than setting up a Communist state, Árbenz desires to establish a "modern democracy"' and mentioned that the president saw FDR as a personal idol. ${ }^{233}$ There were some reports coming out of Guatemala suggesting that the situation was not as desperate as others would suggest. Analysts, however, must look through the reporting and all the information coming in from various collection platforms, and figure out the most logical explanation for events to unfold the way they do. And sometimes analysts, despite adherence to tradecraft standards and best intentions, get it wrong.

Following the coup, Frank Wisner dispatched a small team to exploit the scene of devastation in Guatemala, with the hopes of unearthing definitive proof that Moscow was pulling the strings and isolating individual communists who might be "controlled and exploited." 234 After searching Guatemala City and discovering the PGT's headquarters ransacked, the site exploitation team recovered over 100,000 documents from the local police and military, but

${ }_{234}^{233}$ Cullather, Secret History, 148, citing CIA Information Report No. 00-B-57327, October 10, 1952.

${ }^{234}$ Cullather, Secret History, 106. 
nothing that definitively pointed back to Moscow. In fact, despite a "strong pro-Communist bias," the team could find little to link the Soviets to Guatemala and it seemed that Árbenz was acting "alone, without support or guidance from outside the country." 235

Unfortunately for Guatemala, life only became more difficult under the authority of Armas. Within months of taking charge, Armas destabilized Guatemala by "disfranchising illiterates (two-thirds of the electorate), canceling land reform, and outlawing all political parties, labor confederations, and peasant organizations.... [and] voided the 1945 constitution.” 236 Further, following the removal of Árbenz, Guatemala fell on several years of financial hardship, becoming dependent on "handouts from the United States" of over $\$ 50$ million by the end of 1955. ${ }^{237}$ Political unrest became the norm in Guatemala and in 1957 Armas was assassinated. Decades of repression followed as the right-wing military clashed with indigenous people of the countryside, the Church, and many other leftist factions. Tens of thousands or more were silenced by military oppression and government corruption that lasted for decades in Guatemala.

In hindsight it may seem obvious that Árbenz was not being manipulated by Moscow. CIA analysts, however, had to make the best assessment they could in an attempt to reduce uncertainty for Eisenhower and his staff. Their analysis, though crafted with good intention, was largely incorrect, and as such, constitutes an intelligence failure. A great many monographs have been written about intelligence failures, most in an attempt to determine the causes and mitigate future incidents. Failure is often attributed to either analysts, the collectors/collection platforms, or to policymakers. Other times blame is cast on organizations or policies. Here, in the case of Guatemala, analysts took the information they had from the myriad of collection sources, and drafted assessments in their NIEs and CIBs that were not as accurate as the situation's reality

\footnotetext{
${ }^{235}$ Cullather, Secret History, 107.

${ }^{236}$ Cullather, Secret History, 113.

${ }^{237}$ Cullather, Secret History, 115.
} 
was. Yet analysis is not a precise science and, as stated, sometimes analysts will be wrong. Adherence to tradecraft standards is the best method, however, for reducing the frequency of analytic errors.

When determining what remained to be studied about the 1954 overthrow of Guatemala's president Jacobo Árbenz, historian Stephen Streeter said in his essay Interpreting the 1954 U.S. Intervention in Guatemala: Realist, Revisionist, and Postrevisionist Perspectives that the why could use a more thorough study. Why had the Eisenhower administration decided to launch a covert action operation aimed at overthrowing Árbenz? In determining the why, a study of Ike's sources of information pointed to analysts at the CIA being a primary source of information for the administration when it came to foreign policy decisions. Piero Gleijeses argued that United Fruit Company had lost steam in swaying government officials and that by the time Eisenhower decided to authorize PBSUCCESS, it was because of assessments produced by the CIA. Yet who were these analysts, why had they received so little treatment in the historiography, and what specifically were they saying? This is what this study has sought to investigate via the intersection of diplomatic history, intelligence history, and the use of political science theory and psychology.

This thesis maintains that the 1954 Guatemalan coup cannot be fully understood without looking at what CIA's analysts were assessing about the situation. Further, understanding what additional open-source information was available to Eisenhower and his staff, and then interpreting the interrelationship between the secret intelligence and openly available information aids in understanding why these policymakers came to the conclusion that they did. Analysts offered policymakers information which reduced uncertainty, thereby aiding in the development of policy. Eisenhower and his staff viewed CIA ONE and OCI analysts as credible and valuable 
sources of information vital to the decision-making process. The estimates and secret newsflashes coming from Agency analysts echoed what many media sources and lobbyists claimed, and in doing so validated those openly available sources. Eisenhower and the Dulles brother very likely would have taken pause if CIA's analysts offered insight that was in contrast to what the media was saying. Yet Ike and his administration could feel more confident in their decisions based on having "insider" information coming from secret sources that the newspapers did not have. This is why the voice of CIA's analysts is important to this narrative. ONE and OCI products added the extra impulse needed by Eisenhower to feel comfortable with his decision.

J. Garry Clifford, who penned the essay Bureaucratic Politics for Michael Hogan and Thomas Paterson's Explaining the History of American Foreign Relations, maintains that "the government is a complex, compartmentalized machine and that those running the machine do not always intend what will result." 238 This succinctly describes Eisenhower's administration. This study has aimed to describe the motivation and reasons behind President Eisenhower's decision to authorize the covert overthrow of Guatemala's president. In doing so, the interpretation of intelligence community analytic reporting offers a nuanced narrative that supports or corroborates most post-revisionist studies of this historical event. Clifford states that bureaucratic politics framework "can enrich and complement other approaches." ${ }^{239}$ Many books and articles have been written attributing the decision to early-Cold War hysteria and McCarthyite anticommunism that gave policymakers the impulse to launch the operation. This study's purpose is to give a more detailed account of that by suggesting that there was, indeed, a deep anxiety about communism in the western hemisphere, but that those policymakers who pushed for Árbenz'

\footnotetext{
${ }^{238}$ Clifford, "Bureaucratic Politics," 91.

${ }^{239}$ Clifford, "Bureaucratic Politics," 101.
} 
overthrow did so after being exposed to intelligence reports, from analysts they trusted, that suggested communism had a strong foothold in Guatemala. Furthermore, this study has sought to understand the policy making process in the Eisenhower administration in order to better understand the role intelligence analysis played in that process. This thesis maintains that analysts played a critical function in the decision making process and as a result, in the overthrow of Guatemala's president. Although National Security Council meetings were filled with advisors who had similar agendas in removing Árbenz, and based their decisions on analytic reporting from CIA's Office of National Estimates and Office of Current Intelligence, Eisenhower is understood to be a man who shouldered responsibility for all decision coming out of his office.

Graham T. Allison, author of Essence of Decision: Explaining the Cuban Missile Crisis, is considered by most political scientists to have developed bureaucratic politics as a framework for understanding policy decisions. Allison's argument in Essence of Decision is that:

"instead of behaving like a "rational actor," the Kennedy administration's actions during the [Cuban Missile Crisis] were best explained as "outcomes" of standard operating procedures followed by separate organizations (the Navy's blockade, the CIAs U-2 overflights, and the air force's scenarios for a surgical air strike) and as a result of compromise and competition among hawks and doves seeking to advance individual and organizational versions of the national interest." 240

Allison's message is not that policymakers are incapable of unifying behind a single policy decision, but that each policy maker or department head will have their own agenda and nuanced manner of operating, which could or could not contribute to the successful outcome of a policy decision. Slightly contradictory of the national security framework, bureaucratic politics seeks to "refute those who sought to explain events using "state behavior by system-level or external

${ }^{240}$ Clifford, "Bureaucratic Politics," 91. 
factors alone." ${ }^{241}$ Although Eisenhower spent a good deal of effort unifying his advisors behind the "New Look" policy, "diversity and conflict" still occurred within NSC meetings. As an example, one need only look to the discussion at NSC meeting number 202 in which the Attorney General drove the point of continuing the investigation against United Fruit for antitrust violations despite requests from Secretary Dulles and Eisenhower to delay proceedings for foreign policy reasons. ${ }^{242}$ Allison argues that "policy flows instead from an amalgam of organizations and political actors who differ substantially on any particular issue and who compete to advance their own personal and organizational interests as they try to influence decisions." Secretary Acheson, during the Truman administration, was staunchly against intervention in Guatemala, despite CIA's desire to push forward with operation PBFORTUNE. Under Eisenhower, the Dulles brothers were better able to unite their efforts against Árbenz, but still with organizational agendas and standard operating procedures to guide them. ${ }^{243}$ Furthermore, "organizational routines and hierarchies are so rigid and complex that the president cannot micromanage all that happens. ${ }^{.244}$ In this particular case, Eisenhower discussed options with his NSC staff and close political advisors, but once the decision was made, the execution of the operation was left up to the various departments tasked with implementation of the covert policy.

Critics of bureaucratic politics framework suggest that as a tool for understanding policy decisions, the framework "lets decision makers off the hook by failing to pinpoint

\footnotetext{
${ }^{241}$ Clifford, "Bureaucratic Politics," 92. National Security model maintains that policy decision are a result of a unified cohort of policymakers who have rallied around a common set of core values for the purpose of defining a problem and deciding on a course of action to resolve that problem. See Melvyn Leffler's National Security essay, pages 123-136 in Hogan and Paterson's book.

${ }^{242}$ Clifford, "Bureaucratic Politics," 93 . See Record of minutes from $132^{\text {nd }}$ meeting of the NSC, 18 February 1953, from Ann Whitman Papers, 1953-1961: NSC Series. Box No.: 5, Eisenhower Library, Abilene, Kansas. ${ }^{243}$ Clifford, "Bureaucratic Politics," 92.

${ }^{244}$ Clifford, "Bureaucratic Politics," 94.
} 
responsibility." 245 However, Eisenhower, as discussed in this study, was a man who attributed successes to others while taking any blame upon himself. It is easy to look at those key actors involved in the Guatemala decision-making process and point fingers, especially given the plethora of evidence put forth by scholars. Kowert said it was easy to cast blame on Secretary Dulles, who appeared to be pulling all foreign policy strings. ${ }^{246}$ Still others will argue that Eisenhower, as the chief executive, is responsible for all decisions coming out of the Oval Office. This study makes it easier to attribute some fault to intelligence analysts who were drafting finished intelligence products that suggested Árbenz was a threat whom needed removed. Yet this study is a work of interpretation, and not prescription. The bureaucratic politics framework offers historians "a state-level analytic tool to better explain the timing and mechanics of particular episodes, illuminating proximate as opposed to deeper causes, and showing why outcomes were not what was intended." ${ }^{247}$ Unlike political science studies, this paper does not seek to identify a past problem, analyze the scenario, frame it within a comprehendible paradigm, and then postulate on methods to mitigate future instances of policy failure. This study seeks only to determine why Eisenhower chose to authorize the overthrow of a democratically elected government, and also to introduce new primary sources that add value to existing scholarship. Bureaucratic politics analysis and interpretation allows the historian to "make personality and cognitive processes crucial to understanding..." policy decisions. ${ }^{248}$ The major lesson learned from this study is that presidents must be well informed, engaged, and organize their advisors in a manner best suited to avoid groupthink or deadlock. Yet even when this occurs, mistakes — even tragic ones_ — can still occur. CIA analysts are not infallible, and will

\footnotetext{
${ }^{245}$ Clifford, "Bureaucratic Politics," 95.

${ }^{246}$ Kowert, Groupthink or Deadlock, 32.

${ }^{247}$ Clifford, "Bureaucratic Politics," 96.

${ }^{248}$ Clifford, "Bureaucratic Politics," 101.
} 
get things wrong, and even slightly inaccurate intelligence assessments can have a dramatic ripple effect on foreign affairs. The primary responsibility of analysts, however, is to reduce uncertainty for policy makers in an objective and timely manner. ONE and OCI analysts did this. Historians agree now that Moscow was not pulling the strings in Guatemala. As Clifford says, "those running the machine do not always intend what will result." Eisenhower was engaged. He deliberately sought out information to ensure he was educated before making a decision. He organized and managed his advisors and spent a large amount of time ensuring his staff was reading the same sheet of music. Intelligence analysts were, as Gleijeses notes, "ethnocentric" at times but by the mid-1950s they were much more objective and informed than even five years prior. $^{249}$ The "New Look" policy called for a more aggressive stance against communism, and Árbenz and his communist associates caused great anxiety for the Eisenhower government. His removal, while deemed the best decision by Eisenhower, is understood in twenty-first century hindsight to have been a disaster due to the devastating civil war that ensued shortly after Árbenz resigned. Eisenhower took responsibility very seriously, however, and once a decision was made, he owned it. Ike, a man who penned a letter taking responsibility just in case the Normandy Dday invasion went awry, has been and will remain capable of shouldering the responsibility of his decisions. His proclivity for staff work and advisement was only a check he placed on himself when engaging in decision-making. The ultimate onus for Guatemala, however, was his and his alone.

${ }^{249}$ Gleijeses, Shattered Hope, 361-366. 


\section{APPENDIX 1: PHOTOS}

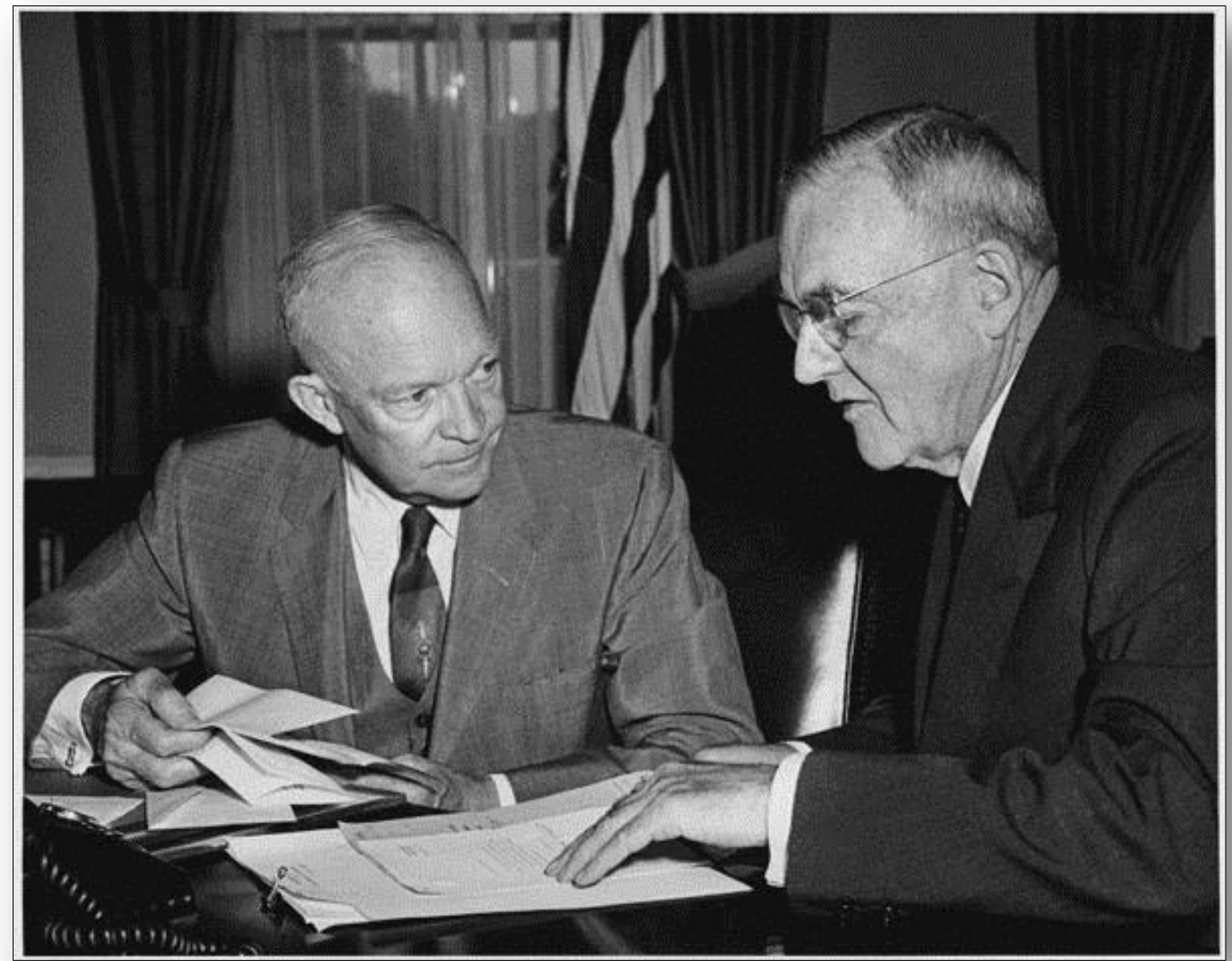

Figure 1: Eisenhower and Dulles discuss foreign policy issues early in Ike's administration. President Eisenhower relied on and trusted Secretary Dulles for guidance on his most sensitive foreign policy decision. 


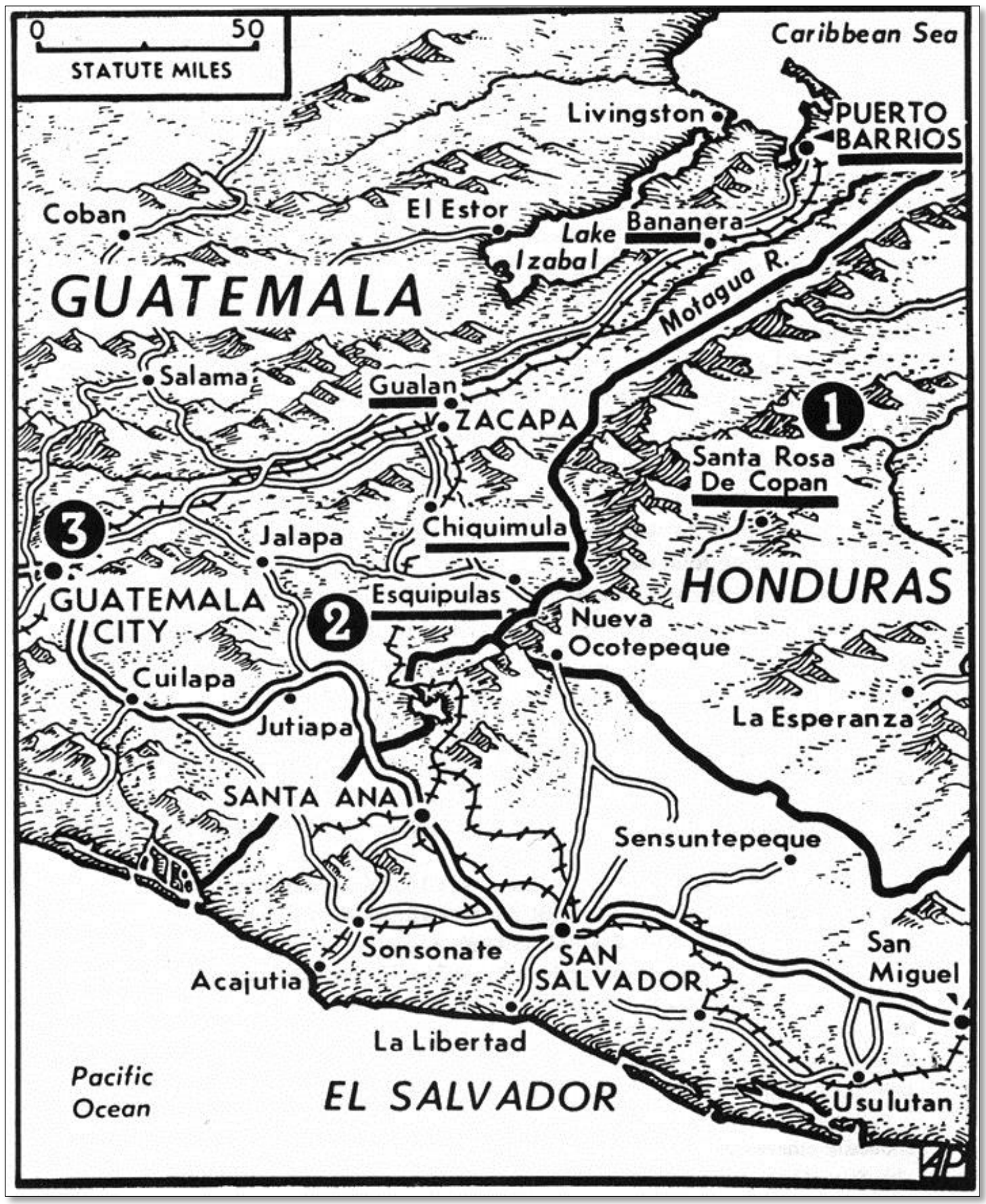

FIGURE 2: Map of Guatemala and border with Honduras and El Salvador.

http://www.latinamericanstudies.org/guatemala/guatemala-1954-map.jpg (accessed 5 June 2017) 


\section{BIBLIOGRAPHY}

\section{Manuscript Sources:}

CREST system (CIA Records Search Tool), once at NARA II in College Park, Maryland, has been fully digitized and can be found at https://www.cia.gov/library/readingroom/.

Dwight D Eisenhower Presidential Library, Museum, and Boyhood Home in Abilene, Kansas, Ann Whitman File, White House Office, National Security Council Staff, Papers 48-61, Dulles, John Foster: Papers, 1951-59.

\section{Government Publications:}

Foreign Relations of the United States, 1952-1954, Guatemala. eds. Susan Holly, David Patterson. US Government Printing Office, Washington, 2003.

Foreign Relations of the United States, 1945-1950, Emergence of the Intelligence Establishment. eds. C. Thomas Thorne, Jr., David Patterson, Glenn LaFantasie. US Government Printing Office, Washington, 1996.

Foreign Relations of the United States, 1952-1954, The American Republics, Volume IV:

Relations of the United States and Guatemala. eds. N. Stephen Kane, William Standford, Jr., William Slany. US Government Printing Office, Washington, 1983.

\section{Books:}

Clark, Robert M. Intelligence Analysis: A Target-Centric Approach. Washington: CQ Press, 2010.

Cullather, Nick. Secret History: The CIA's Classified Account of Its Operations in Guatemala, 1952-1954. Stanford: Stanford University Press, 1999.

Darling, Arthur. The Central Intelligence Agency: An Instrument of Government to 1950. State College: Pennsylvania State University Press, 1990.

Dulles, Allen W. The Craft of Intelligence: America's Legendary Spy Master on the Fundamentals of Intelligence Gathering For A Free World. Connecticut: The Lyons Press, 2006.

Friedman, Max Paul. Nazis \& Good Neighbors: The United States Campaign against the Germans of Latin America in World War II. Cambridge: Cambridge University Press, 2003. 
George, Roger Z and James B Bruce. Analyzing Intelligence: Origins, Obstacles, and Innovations. Washington: Georgetown University Press, 2008.

Gleijeses, Piero. Shattered Hope: The Guatemalan Revolution and the United States, 1944-1954. Princeton: Princeton University Press, 1991.

Haines, Gerald K. and Robert E Leggett. CIA's Analysis of the Soviet Union 1947-1991.

Washington: CIA History Staff, Center for the Study of Intelligence, 2001.

Hall, Wayne Michael and Gary Citrenbaum. Intelligence Analysis: How to Think In Complex Environments. Santa Barbara: ABC-CLIO, LLC, 2010.

Harbor, Tiffany K. Creating a New Guatemala: The 1952 Agrarian Reform Law. Dayton: Wright State University, 2008.

Heuer, Jr., Richard J. Psychology of Intelligence Analysis. New York: Novinka Books, 2006.

Hogan, Michael J. and Thomas G Paterson. Explaining the History of American Foreign Relations. Cambridge: Cambridge University Press, 2004.

Immerman, Richard H. The CIA in Guatemala: The Foreign Policy of Intervention. Austin: University of Texas Press, 1982.

Jones, Benjamin F. Eisenhower's Guerrillas, The Jedburghs, The Maquis, \& The Liberation of France. Oxford: Oxford University Press, 2016.

Katz, Barry M. Foreign Intelligence: Research and Analysis in the Office of Strategic Services 1942-1945. Cambridge: Harvard University Press, 1989.

Kent, Sherman. Strategic Intelligence for American World Policy. Princeton: Princeton University Press, 1949.

Kinzer, Stephen. Overthrow: America's Century of Regime Change from Hawaii to Iraq. New York: Times Books, Henry Holt and Company, LLC, 2006.

LaFeber, Walter. The American Age: U.S. Foreign Policy at Home and Abroad, Volume 2, Since 1896. New York: W.W. Norton \& Company, 1994.

Lowenthal, Mark K. Intelligence: From Secrets to Policy. Washington: CQ Press, 2009.

May, Ernest R. American Cold War Strategy: Interpreting NSC 68. Boston: Bedford/St. Martin's, 1993.

McClintock, Michael. Instruments of Statecraft: U.S. Guerrilla Warfare, Counter-Insurgency, Counter-Terrorism, 1940-1990. New York Pantheon Books, 1992.

McMahon Robert J. The Cold War in the Third World Oxford: Oxford University Press, 2013. 
O’Toole, G.T.A. Honorable Treachery: A History of U.S. Intelligence, Espionage, and Cover Action From the American Revolution to the CIA. New York: Grove Press, 2014.

Schlesinger, Stephen and Stephen Kinzer. Bitter Fruit: The Story of the American Coup in Guatemala. Cambridge: Harvard University Press, 1982.

Smith, Peter H. Talons of the Eagle: Latin America, the United States, and the World. Oxford: Oxford University Press, 2008.

Thomas, Evan. The Very Best Men: The Daring Early Years of the CIA. New York: Simon \& Schuster Paperbacks, 2006.

Thomas, Evan. Ike's Bluff: President Eisenhower's Secret Battle to Save the World. New York: Back Bay Books, 2013.

Troy, Thomas F. Donovan and the CIA: A History of the Establishment of the Central Intelligence Agency. Frederick, Maryland: University Publications of America, Inc., 1981.

Waller, Douglas. Wild Bill Donovan, The Spymaster Who Created The OSS and Modern American Espionage. New York: Free Press, 2011.

\section{Journal Articles:}

Jeffreys-Jones, Rhodri. "Antecedents and Memory as Factors in the Creation of the CIA.” Diplomatic History 40 (2014): 140-154.

Streeter, Stephen. "Interpreting the 1954 U.S. Intervention in Guatemala: Realist, Revisionist, and Postrevisionist Perspectives." The History Teacher 34 (2000). 